\title{
The Referendum Process in Maryland: Balancing Respect For Representative Government with the Right to Direct Democracy
}

Steven G. Shapiro

American University Washington College of Law, steven.shapiro@wcl.american.edu

Follow this and additional works at: https://digitalcommons.wcl.american.edu/facsch_lawrev

Part of the State and Local Government Law Commons

\section{Recommended Citation}

Shapiro, Steven G., "The Referendum Process in Maryland: Balancing Respect For Representative Government with the Right to Direct Democracy" (2013). Articles in Law Reviews \& Other Academic Journals. 1358.

https://digitalcommons.wcl.american.edu/facsch_lawrev/1358

This Article is brought to you for free and open access by the Scholarship \& Research at Digital Commons @ American University Washington College of Law. It has been accepted for inclusion in Articles in Law Reviews \& Other Academic Journals by an authorized administrator of Digital Commons @ American University Washington College of Law. For more information, please contact kclay@wcl.american.edu. 


\section{THE UNIVERSITY OF BALTIMORE LAW FORUM}

A PUBLICATION OF THE UNIVERSITY OF BALTIMORE SCHOOL OF LAW

The Referendum Process in Maryland:

Balancing Respect for Representative

Government with the Right to Direct

Democracy

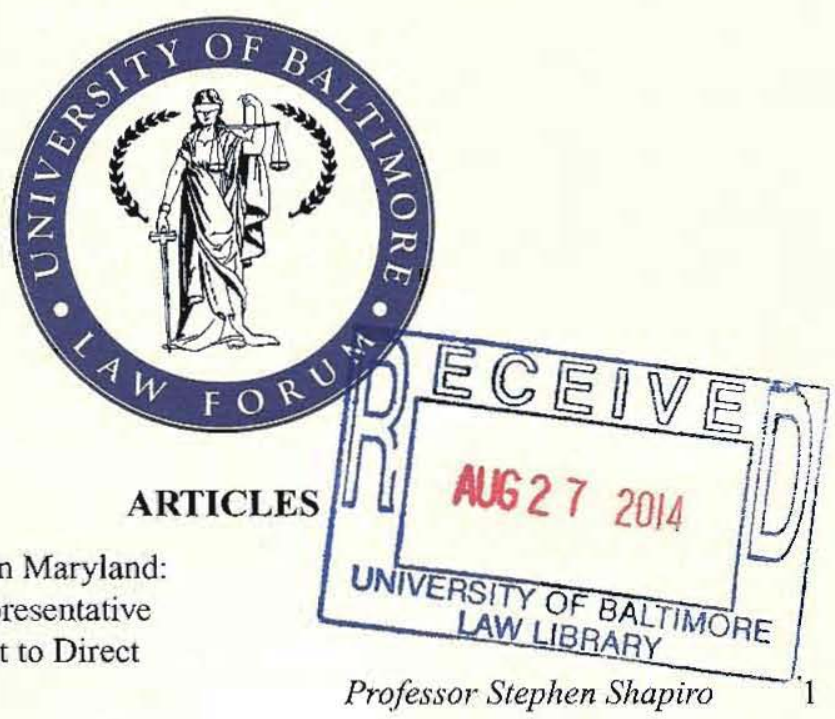

The Future of LGBT Civil Rights and

Equality in Maryland

Aaron S. Merki, The Honorable Shannon Avery, and Anne Blackfield

Pit Bulls - Maryland's Solesky Case

Changes Liability Standard

Susan Rappaport, Kathleen M. Elmore, and Megan $O^{\prime}$ Connor

The Firearms Safety Act and the Future of the Second Amendment Debate

Dominic Lamartina 75

\section{RECENT DEVELOPMENTS}

Coleman v. Soccer Ass'n of Columbia Katelyn Vu 85

Gordon v. State Stephanie Lurz $\quad 88$

In Re Adoption of Sean M. Sarah M. Grago 91

Long Green Valley Ass'n v. Bellevale Farms, Inc. Brett H. Philpotts 94

Maryland v. King

Kristine L. Dietz 97

TransCare Md., Inc. v. Murray

Nicholas B. Hawkins 100

Walker v. State

Brittaney Fabiano 103

Warr v. JMGM Grp. LLC

Molly A. Nicholl 106 


\title{
THE REFERENDUM PROCESS IN MARYLAND: BALANCING RESPECT FOR REPRESENTATIVE GOVERNMENT WITH THE RIGHT TO DIRECT DEMOCRACY
}

\author{
By: Professor Stephen Shapiro*
}

\section{INTRODUCTION}

\begin{abstract}
A pproximately half of the states provide for some type of petitioninitiated, direct legislative action by voters.' The most widespread, well-known, and most used kind is the "initiative" process, by which legislation, and in some states, constitutional provisions, may be brought directly to the voters by the use of the petition process. Twenty-four states have this form of voter initiative. ${ }^{2}$ Most states that have an initiative process also have a related process, usually called a "referendum," or sometimes, more accurately, a "veto referendum," which allows voters to petition to bring a statute passed by the state legislature before the voters in an attempt to have it repealed. ${ }^{3}$ In those states that have both an initiative and referendum process, the overwhelming majority of petitions have involved voter initiatives ${ }^{4}$ with very few if any uses of the veto referendum. ${ }^{5}$
\end{abstract}

\footnotetext{
* Professor of Law, Lniversity of Baltimote School of Law, B.A., Haverford College, 1971, J.D. University of Pennsylvania School of Law, 1976. Professor Shapiro would like to thank his research assistant, Joshua Tart, for his help on the article.

Twenty-seven states have some form of voter initiative or referendum process: Alaska, Arizona, Arkansas, California, Colorado, Florida, Idaho, Illinois, Kentucky, Maine Maryland, Massachusetts, Michigan, Mississippi, Missouri, Montana, Nebraska. Nevada, New Mexico, North Dakota, Ohio, Oklahoma, Oregon. South Dakota, Utah, Washington, Wyoming. M. DANE WATERS, INITIATIVE AND REFERENDUM ALMANAC 12 (2003) [hereinafter "I \& R Almanac"].

2 Alaska, Arizona, Arkansas, California, Colorado, Florida, Idabo, Ilinois, Mane, Massachusetts, Michigan, Mississippi, Missouri, Montana, Nebraska, Nevada. North Dakota, Ohio, Oklahoma, Oregon, South Dakota, Utah, Washington, Wyoming. $7 d$. ${ }^{3}$ Florida. Illinois, and Mississippi have an initiative process, but not a veto referendurn. $l d$.

${ }^{4}$ In the twenty-four states that allow voter initiatives. there have been 346 initiative measures on the ballot in the last ten years. INITATTVE REFERENDUM INST: REPORT ON INITIATIVE USE, 1900-2012 (2013), avallable at http: i/www iandrinstitute.org/IRI\%20Initiative\%20Use\%20(2013-1).pdf.

"I \& R Almanac, supra note 1, at 11 ("In the United States, the initiative process is used much more frequently than the popular referendum process and is considered by many the more important and powerful of the two processes.").
} 
Maryland is one of only three states (the others are Kentucky and New Mexico) that allow only veto referendums, ${ }^{6}$ and do not have an initiative process. ${ }^{7}$ In line with other states that do have both forms of petition process, Maryland voters have, in the past, made very little use of the veto referendum. ${ }^{8}$ Before the 2012 elections, it had been twenty years since any group had mounted a successful drive to have a Maryland statute placed on the ballot for a veto referendum. ${ }^{9}$ In 2011 and 2012, however, three statutes passed by the Maryland legislature were deemed to have received enough valid petitions to be placed on the ballot: Maryland voters were asked. whether to approve or reject legislation legalizing same-sex marriage, ${ }^{10}$ giving in-state tuition at Maryland colleges to certain undocumented immigrant students," and approving a congressional redistricting ${ }^{12}$.

It was widely perceived that the success of getting these laws onto the ballot was, at least in part, due to the innovative use of the internet to help gather voter signatures for the petition. ${ }^{13}$ The Maryland Constitution requires a number of signatures equal to three percent of voters in the most recent gubernatorial election, ${ }^{14}$ which meant that 55,736 signatures were

\footnotetext{
"There is some dispute as to whether the proper plural form of referendum is "referendums" or "referenda." Most articles and books on the subject use "referendums," as will this article. See I \& R Almanac, supra note I, at 33 ("Twelve cities also allow referendums.").

"I \& R Almanac, supra note 1, at 12. There are two other ways that Maryland voters get a chance to approve or reject acts of the General Assembly. One of these is known as the legislative referendum, where the General Assembly itself, in passing a bill, requires approval of the voters before it can go into effect. MD. GEN. ASSEMBLY, http:/msa.maryland.gov/msa/mdmanual/07leg html/gaf.html (last visited Sept. 21, 2013). In addition, any amendment to the Maryland constitution, after being passed by the General Assembly, must also be approved by voters at the polls. Md. Const. art. XIV, $\$ 1$. This article will address only the veto referendum. "See DEP'T OF LEGISLATIVE SERVS., A GUIDE TO THE CTIZEN's POWER OF REFERENDUM IN MARYLAND (2011), avallable ot htrp//ds.state.md.us/data/libandinfser/libandinsfer_docandpub/Referendum2011.pdf.

${ }^{9}$ Id.

${ }^{I 0}$ H.B. 438, 430th Gen. Assernb., Reg. Sess. (Md. 2012); S.B. 241, 430th Gen. Assemb, Reg. Sess, (Md. 2012) (hereinafter referred to as "the Civil Marriage Protection Act").

11 S.B. 167, 428th Gen. Assemb., Reg. Sess. (Md. 2011) (hereinafter referred to as "the Dream Act.").

${ }^{12}$ S.R. 1, 429 th Gen. Assemb., 1st Spec. Sess. (Md. 2011).

${ }^{13}$ See Editorial, Carrying Petition Reform Too Far, BALT. SUN, January 30, 2013, at $26 \mathrm{~A}$.

${ }^{14}$ There are other requirements, including that normally, at least one third of the signatures must be filed by June 1 , and the remainder by June 30 , and that no more
} 
required in $2012 .^{15}$ Even though the three percent requirement is low when compared to the requirements of almost every other state, ${ }^{16}$ it has proven difficult in the past to gather the requisite number of signatures. In prior years, signatures had been collected, in person, by circulators, who either went door to door, or set up tables in public locations. This is an expensive, labor-intensive method of collecting signatures. It also resulted in a large number of signatures being rejected, due to stringent requirements that a voter's signature must match the information on the state's voters' rolls precisely. ${ }^{\text {"7 }}$

Republican Delegate Neil C. Parrott of Washington County created MDPetitions.com. This website allows voters to link to the state's voter registration database and automatically fill out a petition form with the voter's correct information, which can then be signed, witnessed, and mailed to the Maryland Board of Elections. ${ }^{18}$ This method of signature collection was challenged for violating constitutional and statutory requirements: (1) that the signer "include" or "provide" his identifying information (since the information was not personally filled out by the signer) and (2) that the signature be "affixed" in the presence of the person procuring the petition signatures (if the person who signed as the petitioner also signed as the person procuring the signatures). ${ }^{19}$ Opponents also alleged that this procedure would result in large numbers of fraudulent petitions. ${ }^{20}$ The challenge was rejected by the Court of Appeals of Maryland in Whitley $v$. Maryland State Board of Elections. ${ }^{21}$ All three petition drives were certified by the Board of Elections, placed on the November 2012 ballot, and in all three cases, voters rejected the challenge and ratified the laws. ${ }^{22}$

than half of the required signatures come from Baltimore City or any single county. MD. CONST. art XVI, $\$ 3(\mathrm{a})-(\mathrm{b})$.

${ }^{15}$ Whitley $\vee$. Maryland State Board of Elections, 429 Md. 132, 139, 55 A.3d 37 (2012).

See infra notes 187-192 and accompanying text (discussing the percentage of voters needed for a successful referendum in Maryland versus other states).

${ }^{17} \mathrm{MD}$. CODE ANN, ELEC. LAW $8-203$ (2012) requires the signature be "as it appears on the statewide voter registration list of the individual's sumame of registration and at least one full given name and the initials of any other name." The Court of Appeals of Maryland has consistenily enforced a very strict interpretation of this requirement and has rejected a standard that would allow the Board of elections to determine there is "sufficient cumulative information" to identify the signatory as a registered voter. Md. Bd. Of Elections v. Libertarian Party of Md., 426 Md. 488, 493.44 A.3d 1002 (2012); see also Doe v. Montgomery County Boand of Elections, 406 Md. 697,962 A.2d 342 (2008).

${ }_{18}$ Whitley, $429 \mathrm{Md}$ at $135-36,55 \mathrm{~A} .3 \mathrm{~d} 37$.

${ }^{19} \mathrm{Id}$. at $137-38,55$ A. $3 \mathrm{~d} 37$.

${ }^{20} \mathrm{Id}$. at $150.55 \mathrm{~A} .3 \mathrm{~d} 37$.

2. h. at. 132,55 A.3 37 .

${ }^{22}$ See supra notes 10-12. 
Even though all three veto referendums failed at the ballot box, the likelihood that Republicans would continue to challenge any controversial laws passed by the legislature prompted the Governor and some legislators to propose legislation making it more difficult to get a veto referendum on the ballot. ${ }^{23}$ Even if a veto referendum is defeated at the polls, it still usually has the effect of delaying implementation of the legislation, sometimes for more than a year ${ }^{24}$ and results in what can be an expensive and divisive election campaign to defend a law that had already made its way successfully through the legislative process, being passed by both houses of the legislature and signed by the Governor. Democtatic legislators introduced the "Referendum Integrity Act" in the 2013 legislative session, which would have, among other things, made it more difficult to obtain signatures using a website and imposed stricter financial controls and reporting requirements on petition sponsors and circulators. ${ }^{25}$ Some legislators also proposed amending the Maryland Constitution to raise the percentage of voters required to bring a law to referendum.

This article will examine the Maryland referendum petition process to determine whether any changes in the current law should or could be made. This includes whether the legislature should reverse the holding in Whitley, whether it should add additional requirements to and restrictions on the signature gathering process, and whether the percentage of voters needed for a successful challenge should be increased.

First, as a matter of policy, should the law be changed? For example, does it strike the proper balance between respect for the legislative process and allowing for more voices in legislative matters by the public at large?

${ }^{23}$ John Wagner, Marvland Democrats Push for Petition Reform, Citing New Reallty of Imernet Age, WASH. POST, Jan. 28, 2013, at B1 (quoting Governor O'Malley as saying it had probably gotten "a little too easy in Maryland to petition measures to the ballot."). The same article also noted that "House Speaker Michael E. Busch (DAnne Arundel) and Senate President Thomas V. Mike Miller Jr. (D-Calvert) have also aid they are willing to consider changes to the practice." Id.

${ }^{24}$ Laws normally take effect on June 1, following the legislative session in which there are enacted (to give time for petitioners to gather one third of the number of signatures required by that date). If the requisite number of signatures is obtained by the June 1 deadline, the law is held in abeyance. MD. CoNST. art. XVI, $\$ 2$. If the petition is certified for the ballot, it remains inactive until either the following November, or the November aner that (until the next statewide election for the United States House of Representatives, which happens every two years). $I d$. Emergency laws designated as "necessary for the immediate preservation of the public health or safety," and passed by three-fifth of the members of both houses, can go into effect immediately, and remain in effect pending the outcome of the vote. $l d$.

${ }^{25}$ See H.B. 493, 2013 Leg., 433rd Sess. (Md. 2013); S.B. 673, 2013 Leg., 433rd Sess. (Md. 2013). 
Does it provide the right balance between protecting against fraudulent petition signatures and making the process so difficult as to be virtually impossible to get a referendum on the ballot?

Second, do any proposed changes to the process have the potential to be in violation of the United States Constitution? The Supreme Court has held that overly onerous regulation of the petition process can, in some cases. infringe on the First Amendment rights of petition circulators. ${ }^{2 / 5}$

And finally, as to proposed changes that might be both beneficial and constitutional, as a political matter, do they have any significant chance of passage? Some of the proposed changes could be implemented by normal legislative action. However, some of the proposals would require amending the Maryland Constitution, which could be considerably more difficult, requiring a three-fifths vote of both houses of the legislature and approval by the voters.

Section Il of this article will explain the history of the Maryland referendum process and put it into context with similar provisions in other states. Section III will describe the Whitley case and its effect on the legality of the computer-assisted signature-gathering process in Maryland. Section IV will examine some of the proposed changes to the process by looking at their wisdom as a matter of policy, any federal constitutional problems they might raise, and whether they might be politically feasible to implement.

\section{The INITIATIVE AND Referendum PROCESS IN THE UNITED STATE AND MARYLAND}

\section{A. The Initiative Process in the United States}

For the most part, lawmaking in the United States, at the federal, state. and local levels, is accomplished through representative democracy. New laws must undergo a rigorous process of debate and passage by two houses of the legislature, and then either signature by the executive, or an override of an executive veto by a supermajority of both houses of the legislature. ${ }^{27}$ This republican ${ }^{28}$ form of government, which is guaranteed to the states by

\footnotetext{
${ }^{2 t}$ See generally Meyer v. Grant, 486 U.S. 414, 108 S.Ct. 1886 (1988); Buckley v. Am. Constitutional Law Found., Inc, 525 U.S. 182, 119 S.Ct. $636(1999)$; see also infra notes 145-161 and aceompanying text.

27 See generally U.S. CONST. art. I, $\$ 7, \mathrm{cl}, 2 ; \mathrm{MD}$. CONST. art. III, $\$ 28$.

* BLACK'S LAW DKTIONARY 338 (4th pocket ed. 2011) (defining a republican form of government as "a government by representatives chosen by the people."); THE FEDRRALIST NO, 10 (James Madison) (stating "a republic, by which I mean a government, in which the scheme of representation takes place ....").
} 
the United States Constitution, ${ }^{29}$ is "designed to require the creation of consensus before the enactment of laws." $"$;0

Starting in the late 1800 's and early 1900 's, however, there developed, in about half of the states, a competing form of "direct democracy," where citizens, by obtaining the signatures of a certain percentage of voters, could place a proposed law on the ballot for direct adoption by the voters (the initiative), or place a law passed by the legislature on the ballot for possible repeal by the voters (the referendum). The citizen's initiative was championed by populists and progressives, mostly in the western states, to counter what they felt was the inaction of compt state legislatures which were controlled by moneyed interests. ${ }^{31}$

Use of the initiative process has waxed and waned over the years, and in the decade of 1961-1970, when only eighty-seven initiatives appeared on the ballots of all states, had dropped to almost the lowest level since its inception. ${ }^{32}$ Then, in 1978, the voters of California passed Proposition 13, which greatly lowered the state property tax, and this served as a catalyst to revive the initiative process. In the next decade, 1981-1990, the number of statewide initiatives jumped to 271 , and in the following decade, 1991-2000, jumped again to $389 .{ }^{33}$

While it has remained popular with the public, ${ }^{34}$ the initiative process has been severely criticized for a number of reasons. The initiative process prevents deliberation and compromise by bypassing the legislative process. ${ }^{35}$

29 "The United States shall guarantee to every State in the Union a Republican Form of Government . ..." U.S. CoNST, art. IV, \$4; see Pac. States Tel. \& Tel. Co. v. Oregon, 223 U.S. 118 (1912).

30 DAVID BRODER, DEMOCRACY DERAILED: INITIATVE CAMPAIGNS AND THE POWER OF MONEY 2 (2002).

${ }^{31}$ I \& R Almanac, supra note 1; see generally BRODER, supra note 30 at $23-41$ (detailing the history of the initiative movement); see also DAVDD. SCHMDT, CTTIZEN LAWMAKERS 3-24 (1989).

${ }^{32}$ I \& R Almanac, supra note 1, at 7 (A lotal of only eighty -seven initiatives appeared on the ballots of all of the states in that decade. The only other decade that had been lower was 1901-1910, with fifty-six iniliatives, but that was al a time when slates were just beginning to adopt the initiative process).

${ }^{33}$ Id. at 8 .

${ }^{34}$ Americans Want a Direct Say in Government; Survey Results in All 50 States on

Initiative and Referendum, CITZENS IN CHARGE FOUND. (2010), http:/www citizensinchargefoundation, org/files/Full $\% 20 \mathrm{Poll} \% 20$.

\%20Americans $\% 20$ Want $\% 20 \mathrm{a} \% 20$ Direc $\% 20$ Say $\% 20 \mathrm{in} \% 20$ Government.pdf

(noling that no state has ever repealed the initialive/referendum process).

${ }^{35}$ Justin Henderson, The Tyramny of the Minority: Is it Time to Jetison the Ballot Initiative in Arizona?, 39 ARIZ. ST. L.J. 963, 964 (Fall 2007) (quoting The Federalist No. 10 and hudicial Approaches to Direct Democracy, 118 HAR. L. REV. 2748,2758 (2005) ("Critics of direct democracy contend that popular lawmaking fails to 
It can result in popular, but unwise legislation, which can result in unanticipated negative consequences. Unclear wording and lack of legislative history can make it difficult for the courts to interpret legislation passed by initiative. ${ }^{36}$ The result is the passage of inconsistent and contradictory legislation. While it was started as a populist movement against corrupt moneyed interests, the large cost of mounting a successful petition drive and election campaign have resulted in giving corporate interests a disproportionately large role in the process. ${ }^{37}$ It has sometimes been used as a tool by the majority to limit or rollback civil rights for unpopular minorities. ${ }^{3 \mathrm{~B}}$

The voter initiative process also has its defenders, who cite its benefits. Those benefits include greater citizen participation in the political process, a better-informed electorate, ${ }^{39}$ more responsive legislators, ${ }^{40}$ a safeguard against the concentration of political power in the hands of the few, and a means for putting new ideas on the political agenda. ${ }^{41}$

In the early $1900^{\circ}$ 's, several laws passed by initiative were challenged as being unconstitutional on the grounds that the initiative process violated Article IV of the Constitution, which provides that the United States shall guarantee to every state a republican form of government. ${ }^{42}$ The Supreme Court declined to reach the substantive issue, holding that the enforcement of the Guaranty Clause was a non-justiciable political question exclusively

generate the same careful deliberation and compromise that the Founders sought to instill in the lawmaking process." )).

${ }^{36}$ Zachary Hudson, Interpreting the Products of Direct Democracy, 28 Y ALE L. \& POL'Y REV 223, 224 (Fall 2009) ("[T] he interpretation of ballot measures [like initiatives] is often extremely difficult, in part because they often are worded vaguely."): Justin Henderson, The Tyranny of the Minority: Is it Time to Jettison Ballot Initiatives in Arizona?, 39 Ariz. St. L.J. 963, 964 (Fall 2007) ("[L]aws passed through the initiative process are often poorly drafted and difficult for judges to interpret.").

${ }^{37}$ Broder, supra note 30 , at 5 ("Govemment by initiative . . is also a big business, in which lawyers and campaign consultants, signature gathering firms and other players sell their services to aftuent interest groups or millionaire do-gooders with private policy and political agendas.").

${ }^{8}$ BRODER, supra note 30, at 17.

${ }^{39}$ Mark A. Smith, Ballot Initiative and the Democratic Citizen, 64 J. Pol $\$ .892$ (Aug. 2002), available at http:/www jstororg/stable 1520118.

${ }^{4}$ Elisabeth R. Gerber, Legislative Response to the Threat of Popular Initiatives, AM, J. POL. SCl. (Feb. 1996), avalable at http:/www.jstor.org/stable/2111696 (finding one study where data supported the hypothesis that "[1] egislators in states that allow initiatives are expected to pass laws that more closely affect the median voter's preference than legislators in states that do not allow initiatives").

4) SCHMIDT, supra note 31, at 25-30.

${ }^{42}$ U.S. Cosst. art. IV, $\$ 4$. 
committed to Congress and therefore beyond the jurisdiction of the courts, ${ }^{\text {t3 }}$ Although the Court's decision allowed the initiative process to continue in those states that had adopted one. the Suprene Court has never held that state citizens have a constitutional right to have aceess to the initiative process. Some lower courts have refused to recognize such a right, ${ }^{44}$ and because half of the states have never had such a process, it is unlikely that there is such a right. Therefore, it is up to each state whether to have an initiative and/or referendum process. The Court has held, however, that in a state that does have such a process, petition circulators are protected by the First Amendment. 45 States have been found in violation of the First Amendment for putting overly restrictive requirements on circulators and the petition process.

\section{B. The Referentum Process in the United States}

Almost every state that has an initiative process also has the referendum process, which allows voters to bring laws passed by the legislature to popular vote to either approve or reject them. ${ }^{47}$ Unlike the initiative process, the referendum process has been much less frequently used, and has attracted very little attention and discussion by the press and scholars. There are several reasons why the referendum process has been used so jittle, in comparison to the initiative process.

First, there is a much larger universe of possible laws, which some members of the public might favor but which are not passed by the legislature, than there ever could be of laws passed by the legislature, which were controversial enough to be brought to referendum. Also, the initiative is a much more powerful tool that can also be used to reverse action by the legislature. Why use a referendum, which can only negate the recently passed law and restore the status quo anie, when an initiative can both undo the law and provide any proposed alternative? Also, even though the percentage of voters required to place an initiative on the ballot is usually

\footnotetext{
${ }^{43}$ State v. Pac. States Tel. \& Tel. Co, 53 Or. 162, 165,99 P, 427 (1909), appeal dismissed for lack of jurisdiction, 223 U.S. 118, 151 (1912).

${ }^{44}$ Ramcharan-Maharajh v. Gilliland, $48 \mathrm{Kan}$. App, $2 \mathrm{~d} 137,144,286$ P. $3 \mathrm{~d} 216$ (2012).

45 Mever, 486 U.S. at 423 ; Buckley, 525 U.S. 182 (1999); see infia notes 145-159.

${ }^{46}$ Mever, 486 U.S. at $423 ;$ Buckley, 525 U.S. at 192.

${ }^{47} 1$ \& R Almanac, supra note 1 , at 12 . Twenty-seven states have an initiative process, a referendum process, or both. Illinois, Mississippi, and Florida feature an initiative process but no referendum process. Maryland, New Mexico, and Kcntucky feature an initiative process but no referendum process. Arkansas, Arizona, California, Colorado, ldaho, Maine, Massachusetts, Michigan, Missouri, Montana, Nevada, North Dakota, Ohio, Oklahoma, Oregon, South Dakota, Utah, Washington, and Wyoming feature both an initiative process and a referendum process.
} 
higher than that required for a referendum, ${ }^{48}$ the time allowed to gather those signatures is often much longer for initiatives. The signatures for a referendum vote must usually be gathered within just a few months of passage of the law, which requires very quick organizational action by those opposing it. ${ }^{49}$ Those bringing an initiative, however, have much more flexibility as to when to start the process and often as long as a year or more to gather signatures. ${ }^{50}$

Because it has been used much less frequently, and because it is a much less powerful tool, the referendum process has received much less attention and criticism. Much of the criticism leveled at the initiative process ${ }^{51}$ does not apply to the more limited referendum. It is harder to criticize a more limited process that serves mostly as a "fail-safe" to allow the public to challenge an unpopular law passed by the legislature, than to it is to criticize one that allows virtually any and all legislation, no matter how unwise, to be brought to a vote.

\section{The Referendum Process in Maryland}

Maryland is in the almost unique situation of having a referendum process but no corresponding initiative process. ${ }^{52}$ Maryland's constitution was amended to establish the referendum process in 1915. ${ }^{53}$ According to David Smith, one of the foremost historians of the initiative and referendum movement:

By 1900 , reformers had organized a Maryland Direct Legislation League, with A.B. Eichelberger as its president. Ten years later the League claimed "more than 1,000 active working members." In 1914, the League pushed an I \& R

\footnotetext{
${ }^{48}$ See I \& R Almanac, supra note 1, at 37-453 for a detaled description of the process in each state. (i.e., in Oklahoma five percent is required for a referendum, ten percent for a statutory initiative and fifteen percent for a constitutional amendment: in Oregon four percent is required for referendums, six percent for statutory initiatives and eight percent for Constitutional Amendments. Not all states follow this pattern. A few have the same requirements for all three, i.e. Colorado requires five percent for all three. No state, however, has a higher percentage requirement for a referendum than an initiative).

${ }^{49} \mathrm{MD}$. CONST, art XVI, $\$ 3$ (b), cl. 2 (In Maryland, the Constitution guarantees at least thirty days, and in practice the time to gather signatures is only slightly longer than that).

50 I \& R Almanac, stupra note 1 , at 32-33.

st See text accompanying notes $82-85$.

$\$ 2$ See I \& R Almanc, supra note 47. New Mexico and Kentucky also feature a referendum process but no initiative process.

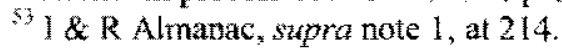


bill sponsored by State Sen. William J. Ogden of Baltimore, but the legislature amended it to remove the Initiative provision. This "Referendum only" amendment passed both houses in 1915 and was ratified by the voters.

The following year the League pressed the legislature for an Initiative amendment. Their bill passed the senate with only six dissenting votes, but was tabled (effectively killed) in the house by a [sixty-six] to [twenty-seven] vote. Never again did an Initiative amendment come close to approval. Charles J. Ogle, secretary of the League in 1916, attributed the failure to the committee chairmen, "a very active lobby against" the Initiative amendment, and rural legislators' fear of the Baltimore masses. ${ }^{54}$

In brief, the Maryland procedure for getting a referendum on the ballot is as follows: the Maryland Constitution provides that no law enacted by the General Assembly "shall take effect until the first day of June after the session at which it may be passed, ${ }^{, 55}$ unless it is designated as an emergency law. "In order to bring a law to referendum, petitions challenging the law must be signed by "qualified voters" totaling at least three percent of the number of votes cast for the governor at the last preceding gubernatorial election. ${ }^{57}$ No more than half of the required number of petitions may come from Baltimore City or any one county.

If more than one-third of the required signatures are filed with the Maryland Secretary of State before June 1, both the time for the law to take effect and the time allowed to submit the rest of the required signatures are extended to the end of that month. ${ }^{59}$ If the State Board of Elections certifies

\footnotetext{
${ }^{54}$ SCHMLDT, supra note 31 , at 239.

5 Mo. CoNst, art. XVI, \&2.

${ }^{50} \mathrm{Id}$. In order to be considered an emergency law, the law must be "necessary for the immediate preservation of the public health or safety" and contain a provision identifying itself as such; the law must also be "passed upon a yea and nay vote supported by three-fifths of all members elected to each of the two Houses of the General Assembly. Finally, "[a]n emergency law shall remain in force notwithstanding such petition, but shall stand repealed thirty days after having been rejeeted by a majority of the qualified electors voting thereon."

$5 \mathrm{MD}$. CONST, art. XVI, $\$ 3$.

MD, CONST, art XVI, $3(\mathrm{a})$.

59 .If an Act is passed less than [forty-five] days prior to June 1, it may not become effective sooner than [thirty-one] days after its passage. To bring this Act to referendum, the first one-third of the required number of signatures to a petition shall be submitted [thirty] days after its passage. If the first one-third of the required signatures is submitted to the Secretary of State within [thirty] days after its passage,
} 
that a sufficient number of valid signatures are submitted by June 30 , then the newly passed statute is placed on the ballot in the next general election at which members of the U.S. House of Representatives are chosen, for approval or disapproval by the voters. ${ }^{60}$

The Maryland Constitution contains several restrictions on the subject matter of laws, which can be petitioned to referendum. The most important of these states:

No law making any appropriation for maintaining the State Government, or for maintaining or aiding any public institution, not exceeding the next previous appropriation for the same purpose, shall be subject to rejection or repeal under this section. The increase in any such appropriation for maintain or ajding any public institution shall only take effect as in the case of other laws, and such increase or any part thereof specified in the petition, may be referred to a vote of the people upon petition. ${ }^{6}$

Although the language is not abundantly clear, it makes a distinction between "any appropriation for maintaining State Government," which is completely insulated from the petition process, versus one "for maintaining or aiding any public institution," for which only previous levels of funding are protected, while increases in appropriations are subject to referendum. ${ }^{62}$ According to the Court of Appeals of Maryland, the purpose of this restriction is to keep the petition process from causing "the State serious financial embarrassment in the performance of its various essential functions." $" 63$

The Court of Appeals has rejected a narrow, but not unreasonable reading of the meaning of "any appropriation for maintaining State Government," which would have protected "merely those which provide overhead expenses, such as salaries and expenses incidental to keeping the government

the time for the Act to take effect and for filing the remained of the signatures to complete the petition shall be extended for an additional [thirty] days." $l d$.

MD. CoNST art. XVI, 2.

MD. CoNST. art. XVI, 8 , amended by ch. 681, Acts of 1977; see also MD. CONST: art XV1, $\S 6$ ("No law, licensing, regulating, prohibiting, or submitting to local option, the manufacture or sale of malt or spirituous liquors, shall be referred or repealed under the provisions of this Article." ).

${ }^{62}$ MD. CONST. art. XVI, $\$ 2$, amended by Chapter 681 , Acts of 1977 , ratified Nov. 7 , 1978.

${ }^{53}$ Kelly v. Marylanders for Sports Sanity, Inc., 310 Md., 437, 456, 530 A.2d 245

(1987) (quoting a 1927 opinion by Attomey General Robinson. 12 Op. Att'y Gen. $228,235-36)$. 


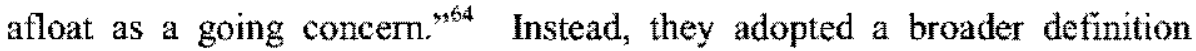
covering any act whose purpose is providing funds for any agency of the government to enable it to perform the duties that are required by law, ${ }^{\text {t5 }}$

In Kelly v. Marylanders for Sports Sanity, the Court of Appeals had to decide whether an act creating the Maryland Stadium Authority and giving it the purpose of planning, funding, and building a baseball stadium at Camden Yards was an "appropriation for maintaining State Government," within the exemption. $^{66}$ The Court of Appeals held that the state acts "pursuant to a valid public purpose when it provides parks or sports facilities, including stadiums, for public recreational activities."67 It also held that even though the Stadium Authority was established as a public corporation, it was also a state instrumentality (a unit of the Department of Economic and Community Development), and therefore, its funding was fully protected by the broader cxemption for "maintaining State Government," rather than the weaker protection only for funding increases for "maintaining or aiding any public institution." 68 In addition, the Court of Appeals took a broad view of "appropriation," holding that even though the act creating the Stadium Authority made no appropriation to support the Authority, it was part of a legislative package that provided funding for the project, and that all of those bills "dealing with the same subject matter, particularly when enacted at the same session, being in pari materia, must be read together in order to determine their proper function. ${ }^{* 9}$ The Court of Appeals also considered it an appropriation, even though the bills expressed "a preference to maximize private investment in the project and to minimize the use of state lottery revenues." 70

This broad reading of the exemption for "appropriations for maintaining state govemment," means that what could be considered significant "policy" decisions, such as whether and where to build a major-league ballpark, can be effectively insulated from the referendum process if they are considered appropriations. ${ }^{71}$ The Court of Appeals has recently made clear, however, that the exemption is not so broad that it covers any legislation that might result in additional expenditure of state funds. ${ }^{72}$

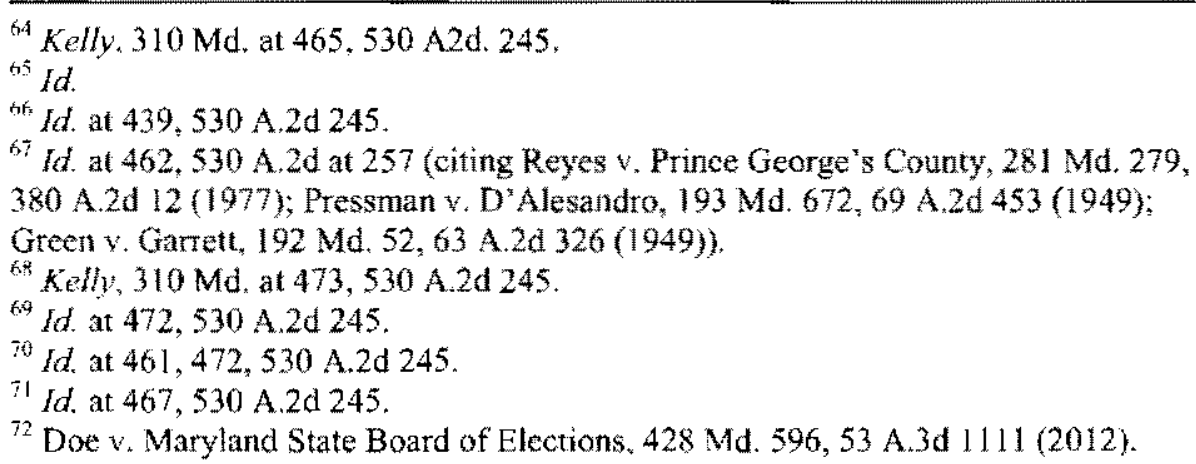


In Doe v. Maryland State Board of Elections ${ }^{73}$, the Court of Appeals held that the Maryland Dream Act, ${ }^{74}$ which provided that certain "undocumented immigrant" students pay the lower, in-state tuition at community colleges in Maryland, was not a law making an "appropriation" within the meaning of the referendum exclusion. The Court of Appeals recognized the Act might result in increased state funding under a previously passed funding formula assigning state funds to public colleges and universities, but that did not, in and of itself, make it an appropriation. ${ }^{75}$ An appropriation is a "legislative act whose primary object is to authorize the withdrawal from the state treasury of a certain sum of money for a specified public object or purpose to which such sum is to be applied." ${ }^{76}$ The Court of Appeals went on to say, "[a]n Act of the General Assembly which relates primarily and specifically to a subject matter of general legislation cannot be converted into an appropriation bill merely because there may be an incidental provision for an appropriation of public funds." ${ }^{77}$ The Court of Appeals concluded by recognizing the effects of further expanding the exception: "[i]ncidental effects are not enough to meet the appropriation exception .... To read the appropriation exception a different way would be to expand the exception beyond its intended purpose, effectively depriving voters the right to referendum." "78

Maryland has possibly the narrowest and mildest form of direct voterinitiated legislative action of any of the states that have such a process. This is due in large part to the fact that the referendum process is the only method to veto legislation, as Maryland lacks a process for citizens to get homegrown initiatives on the ballot, and the limitation on bringing appropriations to referendum. Most of the criticisms directed at the initiative process in other states have been directed at the pernicious effects (both intended and unintended) of the passage of laws drafted by voters. ${ }^{79}$ Criticism has come from both liberals (i.e., criticizing severe limitations on

\footnotetext{
${ }^{73} \mathrm{td}$

${ }^{74}$ The Maryland Dream Act amended MD. ConE ANN., EDUC. \$ 15-106.4 by increasing the amount of time honorably discharged veterans can qualify for in-state tuition benefits and added MD. CODE ANN, EDUC. \$ 16-106.8 which allows qualified immigrants to receive in-state tuition benefits for Maryland community colleges. $2011 \mathrm{MD}$. LAws 870-75.

${ }^{75} D_{o e}, 428 \mathrm{Md}$ at $619,53 \mathrm{~A} .3 \mathrm{~d} 1111$.

${ }^{76}$ Dorsey v. Petrott, 178 Md. $230,245,13$ A.2d 630 (1940)

${ }^{77}$ Doe, 428 Md. at 611, 53 A.3d 1111 (citing Dorsey, 178 Md. at 245, 251, 13 A.2d 630).

${ }^{78}$ Doe, $428 \mathrm{Md}$. at $613,53 \mathrm{~A}, 3 \mathrm{~d} 1111$.

${ }^{79}$ See supra note 37.39 and accompanying text.
} 
taxing and spending which have hampered state governance, ${ }^{80}$ or restrictions on minority rights ${ }^{81}$ ) and conservatives (i.e., criticizing approval of initiatives legalizing marijuana ${ }^{82}$ ). In at least a few states, large numbers of initiatives on the ballot every election cycle have become the norm, ${ }^{83}$ and have placed citizen lawmaking at least on par, if not above, that by the state legisIatures. While a referendum process such as Maryland's can certainly have significant consequences, the fact that an important policy decision by the legislature can occasionally be undone, pales in comparison to states where dozens of voter-generated, special-interest backed laws have appeared on the ballots in some years.

Also, Maryland's referendum process, over the years, has been used very infrequently. Since its passage in 1915 , statewide laws have been petitioned to referendum fewer than twenty times." "In 1970 , voters vetoed a bill concerning the Department of Economic and Community Development, and in 1972 and 1974, they vetoed state aid to public schools. All subsequent referendum petitions, until 1988, failed because of either insufficient signatures or court decisions barring ballot placement." ${ }^{45}$ In 1988 a bill banning cheap handguns was brought to referendum, ${ }^{86}$ and in 1992 a bill guaranteeing certain abortion rights was also successfully petitioned for a vote. ${ }^{87}$ Voters approved both of these by large majorities. 88

${ }^{80}$ See, e.g., IRIS LAV \& ERICA WILLIAMS, CENTER ON BUDGET AND POLICY

PRIORITIES, A FORMULA FOR DECLINE: LESSONS FROM COLORADO FOR STATES

CONSIDERING TABOR (2010).

81 BRODER, supra note 30 , at 17 .

" John Cooke, The medical marijuana debate CON: The constitutional amentment -

-- which Colorado voters approved in 2000 is based on emotional appeals, not research -- is a ploy by marijuana users to achieve the eventual legalization of the drug., DENVER POST, Jul. 15, 2007) at E1.

${ }^{3}$ IRI Historical Database, INITIATIVE \& REFERENDUM INST., http://www iandrinstitute.org/data htm. (last visited Oct. 3, 2013).) (California, for example, had eleven initiatives in 2010, fifteen in 2008, and nine in 2006; Oregon had four in 2010, eight in 2008, and ten in 2006; and Washington had six in 2010, one in 2009, and three in 2008.).

" 94 DEPARTMENT OF LEGISLATIVE SER VICES, OFFICE OF POLICY ANALYSIS, A GUIDE TO THE CITIZEN'S POWER OF REFERENDUM IN MARYLAND (2011). The Department of Legislative Services lists seventeen referendums. In 2012, an additional three laws made the baliot. 2012 General Election Ballot Questions, MARYLAND STATE BOARD OF ELECTIONS, http//www.elections.state.md.us/elections/2012/ballot questions. html (last visited Sept. 8, 2013).

See SCHMDT, supra note 31 at 239.

${ }^{k 6} \mathrm{ld}$.

${ }^{37}$ Immigrant Tuition Plan Seems Headed for 2012 Vote, CBS BALTIMORE (July 8 , $2011,9: 20 \mathrm{AM}$ ), http:/baltimore.cbslocal.com/2011/07/08/immigrant-tuition-planseems-headed-for-2012-vote\%. 
Twenty years then passed without another successful petition drive, until the $201 \mathrm{l}$ and 2012 legislative sessions, when three laws were successfully petitioned to referendum, ${ }^{89}$ thanks at least in part to a new computergenerated petition drive. ${ }^{90}$ Although all three laws were approved by the voters, and therefore the petition drives did not succeed in affecting the law at all, it did raise the prospect that the process would be used more frequently in the future to challenge the passage of controversial or partisan legislation. ${ }^{91}$ This generated a debate, in the legislature and the press, over whether the Maryland process for gathering signatures should be tightenedup to make it more difficult to bring a law to a vote and/or to discourage fraudulent signatures. ${ }^{92}$ The next section of this article will discuss whether there is a need for such changes in the petition process. But first, it is worth discussing whether, as a matter of policy, Maryland should have the petition process at all.

If one makes the assumption that the practice in Maryland would continue to be used infrequently and mostly to challenge controversial social legislation, over which there is a genuine split in public opinion, then it is difficult to come up with an argument to completely abolish the process. To argue against the mild form of public and voter generated legislating in practice in Maryland, one would have to argue against any voter participation in the legislative process (except of course, at the next regular

SCHMTD, supra note 31, at 240; 1992 Presidential Election Official Resuls for Statewile Questions, MARYLAND STATE BOARD OF ELECTIONS, http//www elections.state.md us/elections/1992/results_1992/ballot_questions,hml (last updated Feb, 16, 2001).

${ }^{8}$ Letter from Linda H. Lamone, Adm'r, Md. State Bd. of Elections, to The Hon. Neil Parrot, Md. Gen. Assembly (July 22, 2011) (certifying S.B. 167 for placement on 2012 ballot); Letter from Linda H. Lamone, Adm'r, Md. State Bd. of Elections, to The Hon. Neil Parrot, Md. Gen. Assembly (July 20, 2012) (certifying S.B. 1 for placement on 2012 baltot); Letrer from Linda H. Lamone, Adm'r, Md. State Bd. of Elections, to Mr. Derek A. McCoy, Md. Marriage Alliance, Inc., (July 10, 2012) (certifying H.B. 438 for placement on 2012 ballot).

${ }^{20}$ Computer Generuted Petirions, 29 AMICus CuRIARUM 17, 17 (2012) (discussing Dennis Whitley III, et al $y$. Maryland State Board of Elections, et al).

"Official 2012 Presidential General Elections Results for All State Questions, MARYLAND STATE BOARD OF ELECTIONS, http:/www elections.state.md.us/elections/2012/results/general/gen_qresults_2012 400 1.html (last updated Nov. 28, 2012).

95 Annie Linskey, Immigrant Advocates file suth to toss Tuition Referendum, BALT. SUN, Aug. 1, 2011, http:/articles.baltimoresun.com/2011-08-01/news/bs-md-casalawsuit-20110801 1 tuition-referendum-immigrant-advocates-petition-drive; see Michael Dresser, $\bar{D}$ emocrats Challenge Redistricting Petition Certification, BALT. SLN, July 24,2012 , http:/articles.baltimoresun.com $2012-07-24 /$ news/baldemocrats-ehallenge-redistricting-petition-certification-20120724_1_democratschallenge-map-congressional-districts. 
election, to vote out the legislators who passed the unpopular legislation). That state of the law (no initiatives or referendums allowed at all) is, in fact, in place in half of the states and in the federal government. One could argue that the fact that the United States Constitution, with its systems of checks and balances and no direct voter legislation, has functioned so well for more than 200 years, is proof that citizen legislation is not necessary. One could, however, point to the current gridlock in Congress, as proof that the legislative process is made more difficult by partisan politics, and that an opportunity to bypass Congress and have voters decide certain intractable policy issues is more desirable. Legislative inaction on sensible, or necessary, or popular bills, however, is an argument in favor of allowing initiatives, rather than allowing veto referendums like those in Maryland.

Most of the time, the difficulties of getting a bill through committees in both houses of the legislature, then passed by both houses, then having the often different versions reconciled by a conference committee, then getting the bill signed into law by the Governor, along with the reality that legislators want to get re-elected, make it very rare that a proposed bill will make it into law if opposed by a significant majority of voters. Therefore, even when opponents of a passed bill have enough support to get the required number of signatures to have the law put up for a vote, the law is, more likely than not, going to be approved by voters.

And that is exactly what has happened, at least in the last twenty-five years, in Maryland. Democrats passed all five laws challenged by referendums, and four of the five were in support of liberal causes (handgun restrictions, abortion rights, marriage equality, and fairness for young undocumented students). ${ }^{93}$ Republicans or conservative groups led all of the challenges, and not surprisingly, in a fairly liberal, heavily Democratic state, voters approved all of the laws. ${ }^{94}$ So, whatever position one takes on the issue of whether the initiative/referendum process should exist at all, the arguments that it results in bad lawmaking or that moneyed special interests have too much control in the outcome, cannot be made against the use of the referendum process in Maryland.

In fact, in the current debate over the referendum process in Maryland, no one is suggesting that the process be scrapped entirely. As a practical matter, that would almost certainly not be possible. Doing so would require amending the Maryland Constitution, which requires a three-fifths majority in both houses and ratification by the voters, both of which are unlikely. The right to petition for initiatives and referendums remains very popular in the United States. No state that has adopted the initiative/referendum process

94 See supra notes $86-87,89$.

94 See supra notes 88,91 . 
has ever completely rescinded it, ${ }^{95}$ and some polls have suggested that the process is favored by a large majority in virtually every state."

The real issue in Maryland is whether a rather small percentage of the voters can postpone the effective date of legislation and force an often expensive and divisive election campaign, even when they do not have the electoral majority needed to overturn the law. As long as the petition process was used very infrequently, this was not a problem. If, however, the newly developed computer-assisted petition process has made it easy enough to gather the required signatures so much so that one or more bills is brought to referendum after every legislative session, then the process itself could become problematic, whatever the outcome of the final vote. The current debate centers on whether it has become too easy to gather the required signatures and whether changes in the signature gathering process should be made in order to do so. This issue will be addressed in the next section of this article.

\section{WHTLEY $Y$. MARYLAND AND THE LEGALITY OF THE COMPUTER- Assisted Petition Process}

In Whitley v. Md. State Bd. of Elections, the Court of Appeals of Maryland determined that the web-based process used by MDPetitions.com to gather signatures to petition three recently passed laws to referendum complied with the requirements of the Maryland Constitution and applicable election laws. ${ }^{97}$ Although the same process was used to petition all three laws to referendum, the Whitley case itself concerned the redistricting plan passed by the General Assembly and signed by Governor O'Malley as SB 1 of the 2011 Special Session. ${ }^{9 R}$ MDPetitions.com received advanced determination from the State Board of Elections of the sufficiency of the format of their proposed petition, and began collecting signatures, both with in-person circulators and using a computer assisted on-line program. ${ }^{99}$

As of July 18, MDPetitions.com had submitted 59,201 signatures that were accepted by the State Board of Elections (which also rejected 7,649 signatures) that was more than the number necessary to take the bill to referendum, and therefore, the Board granted final certification to their petition by letter dated July $20,2013 .^{100}$ After the petition was certified, five

\footnotetext{
95 See I \& R Almanac, supra note 1.

* Americans Want a Direct Say in Government, CrTIZENS IN CHARGE Found (2010), http:/ww citizensinchargefoundation.org/files/Full $\% 20$ Poll $\% 20 \% 20 \mathrm{Americans} \% 2$ owant $\% 20 \mathrm{a} \% 20 \mathrm{Direc} \% 20 \mathrm{Say} \% 20 \mathrm{in} \% 20 \mathrm{Govemment}$.pdf.

9 Whitley, $429 \mathrm{Md}$ at 163,55 A.3d 37 .

${ }^{98} \mathrm{Id}$. at $135,55 \mathrm{~A} .3 \mathrm{~d}$ at 37 .

${ }^{99} / d$ at $139-41,55$ A.3 37 .

100 $1 d$, at 144,55 A $3 \mathrm{~d} 37$.
} 
registered voters challenged the validity of the petition's certification by filing a Complaint for Declaratory and Injunctive Relief in the Circuit Court of Anne Arundel County. ${ }^{101}$ They claimed that thousands of the signatures had been gathered by electronically generated petitions that violated the requirements of the Maryland Constitution and sections of the Maryland Election Law. ${ }^{102}$

The Court of Appeals briefly described the on-line petition generating process as:

The site's computer software allowed a user to generate electronically a petition signature page by entering his or her identifying information in specified fields on the website. The registered voter then could print the page, affix his or her signature, complete the required petition circulator's affidavit attesting to the genuine nature of his or her signature, and submit it to the petition sponsor in support of referring SB 1 to the ballot. ${ }^{103}$

More specifically, an individual who logged onto the website and wanted to sign one of the petitions was prompted to supply: first name, last name, suffix (optional), email address, phone number, five-digit zip code, and birthdate. ${ }^{104}$ The software then searched the most recent voter registration rolls made available by the State Board of Elections to determine if the user was a registered Maryland yoter. If so, the screen displayed a list of all Maryland voters living at that address, and the user could download a preprinted petition for him or herself, plus any other registered voters in the household, unless the user deselected them.

The downloaded petition contained all of the requirements for a valid petition, including an approved summary of the bill, and a signature page containing the required identification information ${ }^{105}$ for all registered voters at the address who had not been deselected, a place for each of them to sign and date the petition, and a place for a "circulator" to sign an affidavit attesting to the fact that the petitions were signed in his presence by persons

\footnotetext{
${ }^{101}$ Seetion 6-209 of the Maryland Election Law Article provides a process for registered voters to challenge the certification of any petition on certain specified grounds. MD. CODE ANN, ELEC. LAW, $\$ 6-204$ (a).

${ }^{102}$ Whitley, $429 \mathrm{Md}$. at $145,55 \mathrm{~A} .3 \mathrm{~d} 37$.

10. $I d$. at $135-36,55 \mathrm{~A} .3 \mathrm{~d} 37$.

${ }^{104} \mathrm{Id}$. at $142-43,55$ A $3 \mathrm{~d} 37$.

${ }^{105}$ Signers name as it appears on the Statewide voter registration list, or the individual's surname of registration and at least one full given name and the middle initials of any other names, and current residence address, including house number, street name, apartment number (if applicable) town, and ZIP code. See MD. CODE ANN., ELEC. LAW \& 6-203(a) ser out in full in note 104.
} 
who to the best of his knowledge, were registered voters at his address. ${ }^{106}$ The user was instructed to sign and date the petition, have any other members of the household who chose to do so to sign, and then to sign the certification affidavit as the "circulator" of the petition. 107

Plaintiffs challenged the petitions obtained through this process on two grounds: first, that having the sponsor's computer program pre-fill the signers identifying information violated the statutory requirement that an individual signer "include" that information" and/or the State Board's regulation that the signer shall "provide" such information" ${ }^{109}$, and second, that allowing a signer of the petition to also act as a circulator and attest to his or her own signature violated the requirement of the Maryland Constitution that each petition must have attached an affidavit of the person procuring those signatures that "the signatures were affixed in his presence," and/or the statutory requirement that the affidavit be made and executed by the individual in whose presence all of the signatures on that

${ }^{106}$ The user was also instructed to download the full four "page bill, which is required to be "available" to the petition signer, but does not need to be part of the actual signed petition. They were also instructed to download a pre-addressed envelope for mailing the signed petition back to the sponsors. Whitley, 429 Ma. at $143-44,55$ A.3d 37 .

${ }^{107}$ Id at 144,55 A. 3 a at 37 .

${ }^{108} \mathrm{MD}$. CODE ANX., ELEC. LAW 6-203(a) provides that a petition signer must:

(1) Sign the individuals name as it appears on the statewide voter registration list or the individual's sumame of registration and at least one full given name and the initials of any other names; and

(2) Include the following information, printed or typed, in the spaces provided:

(i) The signer's name as it was signed;

(ii) The signer's address;

(iii) The date of signing; and

(iv) Other information required by regulations adopted by the State Board.

${ }^{109}$ Code of Maryland Regulations $\$ 33,06.03,06 \mathrm{~B}(1)$ provides, in relevant part: "[when signing the signature page, each signer shall ... [p] rovide the following information, to be printed or typed in the appropriate spaces: (A) Date of signing, (B) Signer's name as it was signed, and (C) Current residence address ..." MD. CODE REGS. 33.06.03.06B(1) (2013).

${ }^{110}$ MD. CONST art. XVI, $\$ 4$ requires that "there shall be attached to each paper of signatures filed with a petition an affidavit of the person procuring those signatures that the signatures were affixed in his presence and that, based upon the person's best knowledge and belief, every signature on the paper is genuine and bona fide and that the signers are registered voters at the address set opposite their names." 
page were affixed and who observed each of those signatures being affixed."II

The Court of Appeals found, based on plain language, legislative intent, and the policy of preventing fraud, that the on-line petition process complied with all of the Maryland Constitutional and statutory requirements. ${ }^{112}$

On the issue of whether the requirement that the signer "include" or "provide" certain information, the court determined that the plain meaning of neither word required "that the individual signer be the person who prints or types the required information onto the signature page. Rather, it required that the completed petition page submitted by the individual incorporate the relevant information." "113

As to the purpose of the requirement, the Court of Appeals said that. as opposed to the signature, which provides a "personal attestation ... to evidence support for the petition and to provide a unique identifier, 33 the $^{34}$ requirement to provide name, address, and date of signing "pertain only to the identification of the signer." 11 "s

Whether an individual prints or types personally the information on the signature page, uses a computer program, or has someone else write the information on his or her behalf does not impact the ability of the State Board to identify the signer. The individual still provides to the State Board the petitioning voter's identifying information to aid the Board in validating and verifying the signatures .... 116

Responding to the argument that allowing the information to be provided by the computer program "opens the door to voter fraud," the Court of Appeals accepted that "preventing voter fraud was indeed a concern of the General Assembly in enacting the provisions of Subtitle 6." 118 The Court of Appeals also noted that "there is no evidence that completing electronically a petition makes voter registration information any more readily available to

"MD. CODE. ANN., ELEC. LAW \$ 6-204(a) provides further that: "[e]ach signature page shall contain an affidavit made and execuled by the individual in whose presence all of the signatures on that page were affixed and who observed each of those signatures being affixed."

112 Whilley, $429 \mathrm{Md}$ al $163,55 \mathrm{~A} .3 \mathrm{~d} 37$.

${ }^{113}$ Id. at $153,55 \mathrm{~A}, 3 \mathrm{~d} 37$.

${ }^{114}$ Id. at 154, 55 A, 3d 37 (qtoting Monigomery Cnly. Volunleer Fire-Rescue Ass'n v. Montgomery Cnty. Bd. of Elections, $418 \mathrm{Md}$. 463, 479.80, 15 A.3d 798 (2010)).

${ }^{15}$ Whitley, $429 \mathrm{Md}$ at $154,55 \mathrm{~A} .3 \mathrm{~d} 37$. (quoting Barnes v. State, $236 \mathrm{Md}$. 564, 571, 204 A.2d 787 (1964)).

116 Whitley, 429 Md. at 154,55 A.3d 37 .

${ }^{117}$ Id. at 154,55 A. $3 \mathrm{~d}$ at 73 .

${ }^{118}$ Id. at $154-55,55$ A.3d at 37 . 
an individual intent on committing fraud." $" 119$ The Court of Appeals put the burden on those challenging the procedure to produce evidence of, or at least a cogent argument, explaining why it might increase fraudulent submissions, but found that they had not done so. ${ }^{120}$

The Court of Appeals was probably correct in its interpretation of this provision, and although there was a dissenting opinion by Judge Adkins, ${ }^{|2|}$ that opinion did not mention this issue, and relied entirely on the second issue discussed below. The Court of Appeals' plain language interpretation, while not necessarily the only possible one, is reasonable. More importantly, as a matter of policy, to require anyone to enter data by hand in the 21 st century is just not reasonable. If anything, having the computer program fill in the required information based on state voter lists should improve accuracy over information entered by the petition signer personally. One might wonder how a petition signer could get such basic information as their own name and address wrong, but the Court of Appeals has in the past issued very strict interpretations of the requirement that the voters' name and signature be as it appears on the state voter registration list. ${ }^{122}$ Without access, by some means, to the voter registration list, a signer could very possibly enter the wrong set of names and/or initials and have their petition invalidated. ${ }^{123}$ Even if they were given the correct information by the computer program and instructed to enter it on the forms themselves, they

${ }^{119}$ Id. at 155, 55 A.3d 37 (citing Montgonery Cny. Volunteer Fire-Rescue Ass'n, $418 \mathrm{Md}$, at $492 \mathrm{n}, 6,15 \mathrm{~A}, 3 \mathrm{~d} 798$ (Harrell, J, dissenting) (noting the common practice of using a telephone book directory to commit circulator and petition fraud)).

${ }^{120} \mathrm{Id}$. at $155,55 \mathrm{~A} .3 \mathrm{~d} 37$ ("Whitley fails to point any actual or persuasive indicia that allowing electronically-generated petitions contradicts this purpose. Regardless of whether a yoter completes a paper or an electronic petition, the information required to be included by statute is the same.").

${ }^{121}$ Id. at 163, 55 A.3d 37 (Adkins, J, dissenting, with Battaglia, J., and Barbera, J.).

122. The requirement for both the printed name and the signature is that they appear: "as it appears on the statewide voter registration list or the individual's surnanie of registration and at least one full given name and the initials of any other names." MD. CODE ANN, ELEC. LAW \$ 6-203(a). The Court of Appeals of Maryland has consistently enforced a very strict interpretation of this requirement and has rejected a standard that would allow the Board of elections to determine there is "sufficient cumulative information" to identify the signatory as a registered voter. $\mathrm{Md}$. Bd. of Elections $v_{*}$ Libertarian Party of Md., 426 Md. 488, 493,44 A,3d 1002 (2012); Montgomery Cnty. Volunteer Fire-Rescue Ass' $n, 418 \mathrm{Md}$ at $473,15 \mathrm{~A} .3 \mathrm{~d} 798$; see, e.g. Doe, $406 \mathrm{Md} .697,727-28,962$ A.2d 342 .

${ }^{123}$ Whitley, $429 \mathrm{Md}$. at $155,55 \mathrm{A.3d} 37$ ("Further, because the software confirms electronically that the information entered by a voter matches the information on the voter registration rolls, the process permits individuals to avoid many common errors, such as entering a nickname (instead of a full name), that result frequently in the invalidation of petition signatures." ). 
might make a mistake and not put it on the form in exactly the same way as it was presented to them.

The Court of Appeals also noted that another purpose of the Maryland laws, in addition to preventing fraud, was also to promote voter convenience. ${ }^{124}$ "Allowing a voter to complete a computer-generated petition prioritizes citizen convenience .... Registered voters need not wait for a petition sponsor or circulator to find or stumble upon them, but may participate in the political process on their own initiative." 125

The second issue addressed by the court was whether the same individual could both sign the petition and also the required affidavit attesting to the fact that they had witnessed the signing. This affidavit is required by both the Maryland Constitution and Election Law Article, although the wording differs slightly from one to another. The Maryland Constitution requires that "there shall be attached to each paper of signatures filed with a petition an affidavit of the person procuring those signatures that the signatures were affixed in his presence, and that, based upon the person's best knowledge and belief, every signature on the paper is genuine and bona fide and that the signers are registered voters at the address set opposite or below their names." The Election Law Article requires that "each signature page shall contain an affidavit made and executed by the individual in whose presence all of the signatures on that page were affixed and who observed each of those signatures being affixed.'

When petitions are circulated in person, by someone going door to door or at a shopping mall, for example, the person circulating the petition (the circulator) normally is the one who signs the required affidavit. The instructions on the MDPetitions.com web site, however, suggested that the person who downloaded the petition sign the affidavit attesting to his or her own signature, plus the signatures of other members of the household who signed the same petition. ${ }^{125}$ Therefore, on a large number of petitions, the affidavit attesting to the signature was attested to by the same person who signed the petition. If the required affidavit had to be made by a different person, then all of those self-attested signatures would have been invalid and the required number of valid petitions would not have been met.

The majority opinion by Judge Harrel1 ${ }^{129}$ first viewed the question as whether the same person could serve as both signer and circulator of the petition. The opinion noted that there is no express requirement that a person

${ }^{124}$ 7d. (citing MD. CODE ANN . ELEC. LAW \$ 1-201(5)).

${ }^{125}$ Whitley, $429 \mathrm{Md}$ at 155,55 A.3d 37.

${ }^{126}$ MD. CoNST. art. XVI, $\$ 4$ (emphasis added).

${ }^{127} \mathrm{MD}$. CODE ANN., ELEC. LAW \$6-204(a) (emphasis added).

${ }^{128}$ See Whitley, $429 \mathrm{Md}$. at $142-43,55$ A.3d 37.

${ }^{129} \mathrm{Id}$. at $157-58,55$ A.3d 37 (Bell, C.J., Greene, J, and MeDonald, J., concurring). 
other than the signer of the petition serve as a circulator. ${ }^{130}$ "While it may be accurate to observe that the Legislature provided for the possibility of two distinct classes of individuals, it did not require expressly that the signer and circulator be different persons."

In that statement, the Court of Appeals was correct, but that does not fully answer the question. Another section of the Elections Law Article defines the circulator as "an individual who attests to one or more signatures affixed to the petition," with an additional qualification that the circulator be at least eighteen years of age. ${ }^{132}$ The Court of Appeals was correct that the definition does not specifically state that the circulator must be someone other than the signer. But one would not expect a provision, which basically requires that a signature needs a witness, to include the statement that the witness must be someone other than the signer; that fact would just be taken for granted. Although the Maryland Constitution and the statute do not use the term "witness," the requirement that the person signing the affidavit attest to having "observed" the signatures being "affixed in his presence," is tantamount to requiring a witness.

Where the Whitley court really went wrong was interpreting this language. The Maryland Constitution and the statute, when read together, require an affidavit of the person "procuring those signatures," that they were affixed "in his presence," and that he "observed" each of those signatures being affixed. The Court of Appeals examined each of the relevant words: "procure," "observe," and "presence," individually, and determined that each of them could apply in a situation involving only one person. ${ }^{133}$ For example, the Court of Appeals stated that the term "presence" is normally defined as "the fact of being present," and then went on to say that "an individual is necessarily and metaphysically in his or her own presence." While each of the three words individually could be applied to a single person, the most common usage of each almost always involves at least two persons, not one. When the requirement is looked at as a whole, a court's conclusion that the plain meaning of the constitutional and statutory language is unambiguous that the same person could sign as petitioner and circulator is simply not tenable.

As put by Judge Adkins in dissent:

It [the majority] quotes dictionary definitions for the terms "procure," "observe," and "presence," and reasons that none of these definitions strictly demand the existence of two individuals .... The inferences that the Majority draws from

\footnotetext{
${ }^{130} \mathrm{Id}$. at $158,55 \mathrm{~A}, 3 \mathrm{~d} 37$.

131 Id at $159,55 \mathrm{~A}, 3 \mathrm{~d} 37$.

${ }^{13}$ MD. CODE ANN. ELEC. LAW \$6-101(d).

133 Whitley, 429 Md. at 161-62, 55 A.3d 37 .
} 
these dictionary definitions, however, do not comport with the commonly understood meanings of these terms .... Under the Majority's definitions, the Legislature would have intended a circulator to procure his own signature from himself; observe himself writing his own signature; and affix his signature in his own presence. This formulation is simply not logical. No one speaks in the manner in which the Majority now attempts to define these terms. ${ }^{134}$

In order to understand just how tortured the majority's interpretation of the language is, one should consider the following dialogue:

Person A: "I'd like you to procure the signature of a registered voter on this petition. It must be signed in your presence and you must observe it being signed. Then you should sign an affidavit affirming that you had observed the petition being signed your presence. Then bring the signed petition and your affidavit back to me."

Person B: "OK."

The next day, person $B$ returns and gives person $A$ the signed petition and his affidavit stating that he had observed the petition being signed in his presence.

Person A: "Who was the registered voter whose signature you procured?"

Person B: "My own. I am a registered voter. I signed the petition in my own presence and observed myself signing it. OK? Wait, why are you looking at me like I'm crazy?"

After determining that the language of the statute did not require that two different persons sign the petition and the affidavit, the majority went on to consider the legislature's purpose in requiring the affidavit, and whether that purpose would be satisfied by having the same person both sign and attest to the signature. ${ }^{135}$ The Court of Appeals held that the purpose of the circulator's attestation is to "assure the validity of the signature, ... prevent fraud in the petition process, and provide an additional guarantee of trustworthiness to the signature of the voter .... By requiring that the affidavit attest to the authenticity of the signature and the accuracy of the

${ }^{134}$ Id. at 168, 55 A. 3 d 37 (Adkins, J., dissenting).

${ }^{135}$ Id. at $159 \cdot 60,55$ A.3d 37 . 
information required to be submitted by law, the affidavit is an independent check on the petition signatures. "136

The dissent agreed that the purpose of the attestation was to prevent fraud, but argued that in order to serve this purpose "there must be two different individuals ... a circulator and a signer.... The existence of the separate circulator provides an independent check on the signer. The circulator is able to vouch that the signer did in fact appear before the circulator and did in fact sign the petition." "Is?

While not denying that having a different person sign the affidavit might help protect against fraud, the majority reasoned that the severe criminal penalties for perjury and for fraud in the election process were sufficient to protect against fraud. "The dissent found it "irrelevant whether the Election Law Article has additional safeguards built in that are also designed to prevent fraud. ... [The clourt cannot pick and choose among statutory provisions and decide that the threat of a perjury conviction is a better means of preventing fraud than requiring the circulator and signer to be two different people." $\$ 139$

Because of the Whitley decision, all three referendums were found to have confained sufficient valid signatures to put the issues on the 2012 ballot, where all three failed. Unless the statutory requirements are amended, they will retain the interpretation of the court, and in the future voters will be able to use the petition web site as is, and attest to their own signatures.

The next section of this article will examine whether the Maryland General Assembly should make any changes in the petition process in response to the new on-line process and the Whitley decision approving it.

\section{POSSIBLE CHANCES TO THE MARYLAND REFERENDUM PROCESS}

\section{A. First Amendment Protection for Petition Circulators Established by the United States Supreme Court}

Several changes in the Maryland Referendum petition process were suggested by Maryland legislators, and many of these were contained in the Referendum Integrity Act, which was not passed by the legislature in the 2013 session, but may be introduced in a subsequent session. When evaluating any restrictions or regulation of the petition process, and particularly of petition circulators, one must be cognizant of two United States Supreme Court opinions, holding that the circulation of an initiative

\footnotetext{
136 Id. at 159,55 A.3d 37 .

13 id. at 166.55 A.3d 37 .

${ }^{138}$ Id. at $159-61,55$ A.3d 37 .

${ }^{199}$ Whitey, $429 \mathrm{Md}$, al 167,55 A.3d 37 .
} 
petition is entitled to strong protection under the First and Fourteenth Amendments. ${ }^{140}$

In Meyer v. Grant, the Court held that Colorado's prohibition on paid petition circulators violated their First and Fourteenth Amendment rights. ${ }^{141}$ The Court determined that circulation of a petition involves the type of interactive communication concerning political change that is appropriately described as "core political speech." scrutiny," "143 "ch

The Court did not accept the state's argument that since the initiative is a state-created right, that the state could, therefore impose limitations on the exercise of that right. ${ }^{144}$ The Court distinguished the Posadas case, cited by the state, in which the Court had held that "the greater power to completely ban casino gambling necessarily includes the lesser power to ban advertising of casino gambling."145 The Court said that "Posadas does not suggest that "the power to ban casino gambling entirely would include the power to ban public discussion of legislative proposals regarding the legalization and advertising of casino gambling." "ith "Thus, it does not support the position that the power to ban initiatives entircly includes the power to limit discussion of political issues raised in initiative petitions.

Neither did the Court accept any of the scveral arguments made by the state that the prohibition on paid circulators was neeessary, including the argument that paid circulators might be tempted to disregard their duty to verify the authenticity of the signatures submitted. ${ }^{148}$

No evidence has been offered to support that speculation, however, and we are not prepared to assume that a professional circulator -... whose qualifications for similar future assignments may well depend on a reputation for competence and integrity - is any more likely to accept false signatures than a volunteer who is motivated entirely by an interest in having the proposition placed on the ballot. ${ }^{14}$

\footnotetext{
Alu Mever, 486 U.S. at 428, 108 S.Ct 1886; Buckley, 525, U.S. at 194-95, 119 S.Ct. 636.

14! Mever, 486 U.S. at 419-28, 108 S.Ct. 1886.

${ }^{142} \mathrm{Id}$. at 422,108 S.Ct. 1886

${ }^{143} \mathrm{Id}$. at 420,108 S.Ct. 1886

it4 It at 424,108 S.C. 1886 .

${ }^{145}$ Id. at 424, 108 S.Ct. 1886 (quoting Pusadas de Puerto Rico Assocs. v. Tourism Co, of Puerto Rico, 478 U.S. $328,345-46,106$ S.C. 2968 (1986)).

${ }^{146}$ Meyer, 486 U.S. at 424-25, 108 S.C. 1886 (quoting Grant v. Meyer, 828 F.2d 1446,1456 (10th Cir. 1987)).

14. Meyer, 486 U.S. at 425,108 S.Ct. 1886.

${ }^{148} \mathrm{Id}$ at $425-26,108$ S.Ct 1886 .

149 ld. at 426,108 S.Ct. 1886.
} 
The Supreme Court returned to the question of what restrictions could be imposed on petition circulators ten years later in Buckley v. American Constitutional Law Fotndation, Inc, ${ }^{150}$ another case involving the petition process in Colorado. In Buckley, the Court reaffirmed that petition circulators were protected by First Amendment free speech rights, and that, although the state had an interest in regulating elections to be "fair and honest," any such regulation of core political speech, like petition gathering, must be "nartowly tailored to serve a compelling state interest."

The Court let stand a requirement that circulators be at least eighteen years old, a limitation of the circulation period to six months, and a requirement that circulators attach an affidavit containing the circulator's name and address and a statement that "he or she has read and understands the laxys governing the circulation of petitions." 152

The Court threw out, however, three additional regulations: that circulators be registered voters in the state; that they wear identification badges with their name, identifying whether they were paid or volunteered; and that initiative proponents, as part of their financial disclosure report, list the name and address of all paid (but not volunteer) circulators, the amount of money paid per petition signature, and the total amount paid to each circulator. ${ }^{153}$

Meyers and Buckley, taken together, make very clear that in passing regulations governing petition circulators, states must be very careful not to impose any regulations which would unnecessarily reduce the number of people allowed to be circulators, or in any way burden their right to obtain signatures, unless narrowly tailored to meet a compelling state interest.

There is not too much of a problem applying the Supreme Court doctrine to attempts in Maryland to regulate the old-style, in person, circulation of signatures, where the circulator both convinces the voter to sign and then attests to the signature as valid. For example, one of the proposals put forth in the Referendum Integrity Act was to prohibit compensation of circulators "based on the number of petition signatures collected."154 That provision would be unconstitutional, unless a prohibition on paying circulators "per petition" could be distinguished from Colorado's prohibition (held unconstitutional in Meyers) against paying circulators at all.

Presumably, the argument that it is distinguishable would be based on the proposition that a circulator paid per signature would be more tempted to earn money by accepting invalid signatures than one paid by the hour, allowing the state to argue that it is more necessary and more narrowly

${ }^{150}$ Buckley, 525 U.S. at 186, 119 S.Ct. 636.

${ }^{151} \mathrm{ld}$. at 192, n. 11,119 S.Ct. 636.

${ }^{152} \mathrm{Id}$. at $188-205,119 \mathrm{~S} . \mathrm{Ct} .636$.

${ }^{153} \mathrm{Id}$

${ }^{154}$ S.B. 673, 2013 Leg., 433rd Sess. (Md. 2013). 
tailored to avoid fraudulent signatures than the blanket prohibition in Colorado. The Supreme Court in Meyer did not distinguish circulators paid by the hour from circulators paid per petition, which makes it at least arguable that they might accept the distinction and allow the restriction. However, as a practical matter, most paid circulators throughout the country are paid per signature, ${ }^{155}$ and therefore, the Supreme Court's striking down of a restriction on paid circulator's would probably apply to a restriction on paying them per signature. ${ }^{156}$ Although the answer to whether the state can prohibit paying circulators per petition is not a certain one, the standard to be used and how to apply it is clear: Is the marginal increase in the possibility of fraud between paying circulator's at all and paying them per petition great enough to increase the state's compelling interest in preventing fraud to distinguish it from the holding in Meyers that it is unconstitutional to prohibit all paid circulators?

There is a problem, however, in applying those cases to regulation of the on-line petition process in Maryland, where the two normal functions of a circulator (distributing and obtaining signatures on a petition, and attesting to the validity of the signatures) have been split in two and are not performed by the same person. It is not immediately clear, in that process, who is the circulator entitled to the protections of Meyers and Buckley. This is important to determine, because the rights in Meyers and Buckley do not involve the right to "petition the government" and are, therefore not enjoyed by the signer of the petition. They involve instead, the free speech rights of the circulator (or the organization on whose behalf the circulator is working) to communicate with prospective signers, and to obtain and submit a valid signature from them. The in-person process at issue in Meyers and Buckley involved the circulator first convincing the voter to sign and then (done at the same time and by the same person) signing an affidavit that the signature was an authentic signature of a registered voter.

When a Maryland voter downloads a petition from MDPetitions.com, signs it, then, as their own circulator, attests to the signature's validity, they are not really serving as a circulator in a way which would make the Supreme Court opinions applicable to them. Both Meyers and Buckley are based on the free-speech rights of the circulator to communicate with and

\footnotetext{
${ }^{155}$ BRODER, wupra note 30 , at $52-60$.

${ }^{136}$ In fact, there is reason to believe, that although neither the Colorado statute nor the Supreme Court diseussed whether circulators in Colorado were paid by the hour or by the signature or both, and whether or not this might make a difference in the outcome, that circulators in Colorado were, in fact paid per signature. See Independence Inst, v. Gessler, No. 10-CV.00609-PAB-MEH, 2013 WL. 1302391, at *5-6 (D. Colo. Mar. 29, 2013) (suggesting that some circulators in Colorado are paid per signature). In the later Buckley case, one of the prohibitions struck down by the court was Colorado's requirement that sponsors list "the amount of money paid per signature." Buckley, 525 U.S. at 203-04, 119 S.Ct. 636 .
} 
convince a voter to sign the petition. When a Maryland voter serves as his or her own circulator, there is no communication process going on between the circulator and the voter, and, therefore, there is no "interactive communication" deserving of protection as "core political speech."

In the on-line petition process, it is the petition sponsor, MDPetitions.com, which is the person (entity) trying to persuade the voter directly, on-line, rather than through a hired or volunteer person serving as an in-person circulator. Since the website is the one communicating with and obtaining the voter's signature, it is the one deserving of the free speech protection given circulators in Meyers and Buckley. In other words, MDPetitions.com is serving as both the "sponsor" of the petition process (the one who organizes, solicits funds for, and usually hires individual circulators in an attempt to get a referendum on the ballot) and also the circulator (the one who obtains the voter's signature).

Some of the proposed new regulations require anyone "supporting the collection of signatures for a petition" to form a "ballot issue committee" and comply with certain financial disclosure requirements as to how they raised and spent funds in support of the petition drive. ${ }^{157}$ This would seem to be regulating them as sponsors of the petition and not as circulators, and might subject them to compliance with financial disclosure laws. The Supreme Court clearly distinguished between requirements for sponsors to disclose how much was paid to individual circulators, which they threw out, as an invasion of the circulators' rights, from other financial disclosure requirements of the sponsors. ${ }^{158}$ Although the Court specifically declined to decide the constitutionality of those additional financial disclosure requirements placed the petitions' sponsors or supporters, ${ }^{159}$ they seemed to approve of their purpose.

Through the disclosure requirements that remain in place, voters are informed of the source and amount of money spent by proponents to get a measure on the ballot; in other words, voters will be told "who has proposed [a measure]," and "who has provided funds for its circulation."

The dispute in Whitley, and some of the regulations of the process being proposed in the Referendum Integrity Act, involve who may attest to the signature "as circulator." Maryland law defines a circulator as the person

\footnotetext{
${ }^{157}$ H.B. 493, 2013 Leg. $433 d$ Reg. Sess. (Md. 2013).

${ }^{158}$ Buckley, 525 U.S. at $203-04,119$ S.Ct. 636.

${ }^{159} \mathrm{Id}$. at $201,119 \mathrm{S.Ct} .636$. "We express no opinion whether these monthly report prescriptions, standing alone, would survive review." $1 d$.

160 Id. at 203,119 S.Ct 636 .
} 
attesting to the signature. ${ }^{161}$ This, however, was almost certainly written with the in-person situation in mind, where that same person would have been the one who solicited the voter's signature, and that person would have received the protections of Meyer and Buckley. Regulating the person who merely attests to the validity of the signature, but did not procure it, would not implicate the First Amendment rights of either the signer or the witness. It might, however, violate the rights of the sponsor, (i.e., MDPetitions.com), if it were found to unnecessarily burden their right to seek and obtain valid signatures. ${ }^{162}$

Any change in Maryland law should take note that there is a distinction between a "circulator" (one who attempts, either in person or on-line, to obtain a valid signature on a petition), from a "witness," who attests to the validity of the signature (which may or may not be the same person who circulated the petition). Present Maryland law treats them both the same, which is true of in-person solicitation, but not true of the on-line process. This is an important distinction, since whether a regulation is constitutional might depend on whether it is applied to the person or organization obtaining the signature versus the person attesting to the validity of the signature.

\section{B. Should the Legislature Act Now to Make any Changes in the Petition Process?}

Whether or not one believes the legislature should preserve the status quo, or pass legislation to make it more difficult to bring a law to referendum, is in great part determined by one's view on the referendum process in general. Those who see it as an unnecessary, wasteful intrusion into representative government will want to see the process tightened up and made more difficult. Those who see it as a valuable, democratic way to empower the voting public to protect themselves from an over-reaching legislature will want to see it made easier to procure the required signatures. ${ }^{163}$

\footnotetext{
${ }^{161}$ MD. CODE ANN., ELEC. LAW $\$$ 6-101(d).

${ }^{162}$ See supra text accompanying notes 145-48. Since there is a right to communicate with a voter to try to obtain his signature on a petition, but no right to be able to bring a law to referendum in the first place, one could argue that as long as MDPetitions.com was allowed to convince the voter to sign, regulations making it difficult to get that signature to "count" toward the number required for a valid Referendum would not violate their rights.

${ }^{163}$ In Maryland, this also probably divides along republican/conservative (pro referendum) and democratic/liberal (anti-referendum) lines. This is not necessarily a matter of ideology, but more likely born out of practicality. Since the Maryland legislature and Govemor are more likely to be democratic and liberal, the laws they pass would more likely be opposed by conservatives or republicans, who would view the referendum process as a last-ditch effort to derail legislation to which they were opposed.
} 
As noted earlier in this article, Maryland has one of the most limited in scope, ${ }^{164}$ least used initiative/referendum processes in the country, ${ }^{165}$ among those states that have any such process. Until very recently it would have been difficult to argue for making the process more difficult, unless one did take the view that the entire idea of giving voters a chance to force a vote to repeal legislation should not be allowed at all. ${ }^{160}$

Things changed, however, in 2011-2012, when the on-line assisted petition process, approved by the Court of Appeals of Maryland in Whitley, helped bring three different pieces of legislation to referendum. Although all three referendums failed and the legislation survived, it raised the question as to whether the new process made it too easy to bring legislation to referendum, either by making it easier for referendum proponents to reach more citizens (which clearly was true) or by facilitating significantly more fraudulent petitions (which has not been proven, and might or might not be true). This raised the specter of referendum challenges every year, challenging any controversial legislation passed in every legislative session.

As a result, at the beginning of the 2013 legislative session, Governor Martin O'Malley told the news media, "ii]t's probably been made a little too easy" to subject a law to a referendum vote, and his spokesperson confirmed that the Governor thought the process "needs to be looked at." ${ }^{16}$ ? Senate President Thomas Mike Miller implicitly questioned the Whitley decision by asking whether electronic signatures should be verified by someone other than the people who gave them. ${ }^{168}$ House Speaker Michael Busch suggested that lawmakers should reconsider the number of signatures required, since that threshold was set in the days when they were collected door-to-door. He was quoted in the Ballimore Sun as saying "[i]t should be fair . . . I I don't think it should be easy; I don't think it should be hard. . . W We're a representative democracy, and we're sent here to make decisions. We can't have a referendum every time someone doesn't like them.".169

On the other side of the debate, Delegate Neil Parrot, who developed the on-line system, responded that "[t]his is a fundamental right to the citizens of

${ }^{164}$ See supra notes 6-7,64 and aceompanying text. Maryland law allows only repeal of legislation, not the passage of new legislation and restricts the right to bring state appropriations to a vote.

${ }_{165}$ See supra notes $9,93-94$ and accompanying text. Until 2012 , twenty years had passed since legislation had been brought to a referendum vote.

T6t See supra notes 1-5; see sapra text accompanying notes 77-86. This is not an unreasonable position to take, since half of the states and the federal government have never had any form of initiative or referendum process.

${ }^{167}$ Erin Cox, Petition Process Under Scrutiny: Assembly Leaders Wetgh Restrictions on Referendums, BALT. SUN, Jan. 9, 2013, at $2 \mathrm{~A}$.

${ }^{168} 1 d$.

169 
Maryland. It's an important right that needs to be preserved." The Baltimore Sum reported that the "nonpartisan watchdog group Common Cause said the petition process should be protected, calling Maryland "[o]ne of the few states that doesn't have a very robust referendum history." "\$17t

In the 2013 legislative session, some Democrats introduced the Referendum Integrity Act, ${ }^{172}$ which would have made the petition process more difficult in a number of ways, including reversing Whitley by requiring that the voter who signs the petition could not be the same person who serves as the circulator attesting to the validity of the signature, requiring circulators to take an on-line training course, and prohibiting circulators from being paid based on the number of signatures they procured. ${ }^{13}$

The title of the bill implies that it was mainly directed at the "integrity" of the process, i.e., preventing fraud and providing for financial accountability for those groups supporting a petition drive. The chief sponsor of the bill, Delegate Eric Luedtke stated, "[t]he goal of the bill is to make the process fair, accountable and free of fraud." 174 Although many sections of the bill are clearly directed at preventing fraud, other sections, and the overall effect of the bill, and most likely the intent of the sponsors, would have made it much more difficult to mount a successful petition drive. The Baltimore Sun, in an editorial entitled "Carrying Petition Reform Too Far," although admitting that "some changes are needed," argued that the ones being proposed were more "drastic," than was necessary. ${ }^{135}$ The Referendum Integrity Act was not passed by the 2013 General Assembly.

Many people were looking to see what happened after the passage of any controversial legislation in the 2013 session, to see if the referendum process

\footnotetext{
${ }^{170} \mathrm{Id}$.

171 Id. This statement is probably true, as it relates to those states that do have a referendum/initiative process, but it ignores the fact that approximately half the states have no referendum or initiative process at all. In tnith, Maryland is not the only state without a robust referendum history.

$1 / 2$ H.D. B. 493,2013 Leg., 433 rd Sess, (Md. 2013); S. B. 673, 2013 Leg., 433 rd Sess. (Md. 2013).

${ }^{133}$ Id. Each of these provisions will be discussed in this article. The bill also added a number of financial disclosure requirements on any group supporting the collection of signatures for a referendum petition. The financial disclosure requirements, while important, are beyond the scope of this article and will not be discussed herein. See supra text accompanying notes $26,162-63$; see also infra 202 .

${ }^{4}$ Marta H. Mossburg, Editorial, Hypocrisy on Voter Access. BALT. SLX, Feb. 27. 2013 , at 21 (quoting Del. Eric G. Luedtk, as quoted in Glynis Kazanjian,

Democrats' Bill on Referendums Denounced as Voter Suppression by GOP Delegate, MARYLANDREPORTER.COM (Feb. 20, 2013, 11.59 PM), hitp:/marylandreporter com/2013/02/20/democrats-bill-on-referendums-denouncedas-voter-suppression-by-gop-delegate).

175 Editorial, Carrying Perition Reform Too Far, BALT. SUN, Jan. 30, 2013, at 26.
} 
would become a yearly event, providing a valid reason, therefore, for making the process more difficult. The results from that legislative session, however, are inconclusive.

The two most controversial pieces of legislation passed in 2013 were a comprehensive gun control law, ${ }^{176}$ which, among other things, completely banned "assault weapons" and a law repealing the death penalty. ${ }^{i n}$ Virtually everyone expected the gun bill to be brought to referendum. As to the death penalty repeal, on the first day of the 2013 session, even before the bill was introduced, Senate President Thomas Mike Miller predicted that the bill would pass, and then matter-of-factly predicted it would be petitioned to referendum, for vote in the 2014 election. ${ }^{178}$

As it turned out, however, although both bills passed in the legislature, and petition drives were mounted against both bills, neither gathered enough signatures to bring the laws to a vote. The drive to petition the gun bill was, according to the person leading the drive, "hampered by controversy within the gun rights community over how to best attack the law," and that "a group of Republican lawmakers [although opposed to the law] deliberately discouraged people from signing it."179 Several gun groups, including the National Rifle Association had announced they would not endorse a petition drive and instead would focus energy on a lawsuit to challenge the constitutionality of the legislation, and the general consensus was that with the NRA's support the petition effort would clearly have succeeded. There was also a petition drive mounted against the repeal of the death penalty, which was unsuccessful, ${ }^{181}$ but this also was not a good test of how easy it is to mount a successful drive, since there was no real organized group or organization strongly opposed to the law.

Although there were no successful petition drives this year, "the vote is still out" on whether successful referendum drives will become an annual

${ }^{176}$ S. B. 281, 2013 Leg. 433rd Sess. (Md. 2013) (approved on May 16, 2013) (Firearm Safety Act, Ch. 427.2013 Md. Laws 4195).

S. B. 276, 2013 Legis., 433rd Sess. (Md. 2013) (approved on May 2, 2013) (Death Penalty Repeal - Substitution of Life Without the Possibilities of Parole, Ch. 156, 2013 Md. Laws 2298).

${ }^{178}$ Erin Cox, $O$ Walley to Focus on Guns: Miller Foresees Repeal of Death Penalty. Then Referendum, BALT. SUN, Jan. 10, 2013, at 1.

${ }^{179}$ Erin Cox, Petition Effort to Overturn Gun Law Fails: Promised Court Challenge by NRA and Others Still Looms, BALT. SUN, June 2, 2013, at 3 (quoting Susan Payne).

${ }^{180^{\circ}} I d$. "We didn't want to put a fundamental right up to a public vote," said Patrick Shomo, president of Maryland Shall Issue, a gun rights group. "If any one of our groups, or if the NRA, bad snapped its fingers, we would have gotten the petition signed. We could have very easily held this thing off until next year, but we're very interested in taking it head-on." Id.

${ }^{181} I d$. 
affair or not, and therefore whether there is a problem needing legislative fixing or not. For this reason, for those taking a middle-of-the-road position on referendums (they are a useful safeguard against governmental overreaching, but shouldn't become an extra hurdle that any controversial legislation has to go through), the best course of action might be to wait a few more years to see if the process is being abused.

The next sections of this article will examine several of the key proposals presented in the Referendum Integrity Act and elsewhere to discuss whether they represent good policy, whether as a practical political matter they have a chance of passage, and finally if they run afoul of several United States Supreme Court cases giving strong First Amendment protection to petition circulators and sponsors.

\section{Should Maryland Increase the Percentage of Voters' Signatures Required to Bring a Law to a Referendum Vote?}

One remedy for those who thought that it had become too easy to bring a law to a veto referendum in Maryland, which would not involve changing the petition process itself, would be to increase the percentage of voters' signatures required. This could be justified by the fact that Maryland, with a requirement of three percent of the total votes cast in the last gubernatorial election, has the lowest required percentage of any of the twenty-four states that allow veto referendums. ${ }^{182}$

One state requires fifteen percent, ${ }^{183}$ four states require ten percent, ${ }^{184}$ three states require six percent, ${ }^{185}$ and nine states require five percent. ${ }^{186}$

\footnotetext{
${ }^{182}$ Most states, as does Maryland, require a certain percentage of votes cast in the last gubernatorial election. There are, however, a few departures from this fact. A few states use the vote totals from the last general election (Alaska, Idaho, and Wyoming) and one state uses the last presidential election (Utah). See supra and notes $1-2,50,55$. Neither of these would seem to yield a materially different result than using the last gubernatorial election. Two states, rather than using the number of actual voters, use either the percentage of registered voters (Nebraska) or the percentage of the population over eighteen (North Dakota). See supra notes 1-2. These two methods would make it significantly more difficult to reach whatever the required percentage is, than using the number of actual voters. The Now York Times cited a proposal by Delegate Richard Madaleno, Jr, which would have raised the requirement in Maryland to five percent of registered voters. John Wagner, Maryland Democrats Push for Petition Reform, Citing New Reality of Internet Age, WASH. POST, Jan. 28, 2013, at B4. This proposal would have more than tripled the number of signatures required and was deservedly criticized as too high by the Baltimore Sun. Editorial, Carrying Petition Reform Too Far, BALT, SUN, Feb. 27, 2013 , at 21 .

${ }^{183}$ Wyorning. See I \& R Almanac, supra note 1.

${ }^{184}$ Alaska, Nevada, New Mexico and Utah. See I \& R Almanac, supra note 1.
} 
Only four states require less than five percent: Washington and Oregon with four percent, Massachusetts with three and a half percent, and only Maryland bringing up the rear with three percent. ${ }^{187}$

It would seem reasonable, therefore, to bring Maryland in line with the majority of states and to raise the threshold from three to five percent. Of course, the mere fact that Maryland has the lowest percentage requirement does not, in and of itself, prove that it needs to be raised, but it does call into question whether such a small percentage of Maryland voters should be able to delay and force an election campaign about a law duly passed by the legislature and signed by the governor.

Moreover, in actuality, the percentage of registered voters who need to sign is considerably smaller than three percent of the voters who are eligible to sign. That is because although the required signatures are based on three percent of people who actually voted in the last gubernatorial election, all registered voters, whether they voted in the election or not, are eligible to sign. ${ }^{189}$ In the 2010 elections since only approximately fifty-four percent of the number of registered voters actually voted in the gubernatorial election, ${ }^{169}$ what was really required was closer to one and six-tenths percent of those registered voters eligible to sign. And, of course, not everyone who is eligible to register to vote does so, making the percentage of the total voting age population required to put a referendum on the ballot even smaller. In the case of the 2012 referendums, 55,736 signatures were needed, which was three percent of the number of persons who voted in the gubernatorial election of 2010 , but represents only one and twenty-sixhundreths percent of the total voting age population of Maryland, which was

${ }^{185}$ See Initiative \& Referendum Institute, University of Southern California, http://www.iandrinstitute.org/statewide_i $\% 26 \mathrm{r}$.htm (last visited October 3, 2013) (These states include Arkansas, Idaho, and Ohio).

${ }^{186}$ See id (Arizona, California, Colorado, Michigan, Montana, Nebraska, Oklahoma. South Dakota and Missouri. Nebraska requires five percent of registered voters, rather than voters in the last election, so when compared with the other states, its requirement is actually more than five percent).

${ }^{187}$ See id. (Nebraska has a requirement of two percent of the entire population over the age of eighteen (people eligible to register to vote, rather than actual voters) For comparison purposes this would make its percentage requirement of actual voters much higher, probably four or five percent).

${ }^{188}$ See Doe, 406 Md. at 724,962 A.2d 342.

${ }^{189}$ See Maryland State Board of Elections, 2010 Gubernatorial General ElectionVoter Turnout, www.elections.state.md us/elections/2010/turnout/general/2010_General_Statewide. html (last visited October 3, 2013). 
$4,420,588^{190}$ The result is that just over one percent of the adult population can put a duly passed law on hold, sometimes for more than a year, and force an election campaign and vote on the issue.

Therefore, if the General Assembly felt that with internet-aided petitions, it had become too easy to get a referendum on the ballot, they could justiftably raise the required percent of those who voted in the last gubernatorial election from three to five percent, bringing Maryland into line with the average among states with a referendum. ${ }^{191}$ Presumably, this would not raise federal constitutional questions under Meyers and Buckley, since it would not, in any way interfere with the ability of proponents or ctrculators of petitions to communicate with prospective voters or obtain their signatures on valid petitions. ${ }^{192}$ Each state may clearly decide for itself whether to have a referendum process, and if so, how many valid petitions are required.

The biggest obstacle to raising the required percentage is not legal, but practical, since it would require an amendment to the Maryland Constitution, which specifies the three percent requirement. ${ }^{193}$ In order to do so, it would have to pass both houses of the legislature by a three-fffths vote and also be voted on by the public at the next general election. ${ }^{134}$ It is unlikely that the proponents could accomplish this. As a practical political matter, if the referendum process is to be modified, it would most likely have to be accomplished by an amendment to the Election Laws, and one which would not be inconsistent with the state constitutional requirements. ${ }^{195}$

${ }^{190}$ See American Fact Finder, United States Census Bureau, http //factfinder2.census gov/faces/tableservices/jsf/pages/productview.xhtml\%src=bk mk (last visited September 10, 2013).

${ }^{191}$ John Wagner, Md. Democrats Seek to Revise Petition Process, Citing New Realities of Internet Age, WASH. POST, January 28, 2013, at BOI (If the percentage were raised, it should be, as it is presently in Maryland and most other states, the percentage of the number of actual voters, not of the number of registered voters. The Washington Post reported that State Senator Richard Madaleno, Jr. was planning to sponsor a bill to raise the requirement to five percent of all registered voters, which would have more than tripled the amount required in 2012 from 55,736 to about 188,000 ; that would jump Maryland from one of the lowest to one of the highest percentage requirements. Delegate Madaleno apparently did not, in fact, introduce such a bill.).

${ }^{192}$ See generally Meyer, 486 U.S. 414, 108 S.Ct. 1886; Buckley, Inc. 525 U.S. 182, 119 S.Ct. 636 .

${ }^{193} \mathrm{MD}$. CONST, art. XVI, 4 .

${ }^{194} \mathrm{ld}$

195 The General Assembly shall prescribe by law the form of the petition, the manner for verifying its authenticity, and other administrative procedures which facilitate the petition process and which are not in conflict with the Arricle." MD. CONST. art. XVI, \& 4 . 
D. Should the Legislature Reverse the Holding in Whitley That the Voter Who Signs the Petition Can Be the Same Person Who Serves as "Circulator" and Attests to the Validity of the Signature?

In Whitley, the Court of Appeals of Maryland held that the same person who signed the petition could also sign as the circulator, attesting that the petition was "affixed in his presence." 196 The question to be addressed here is whether the legislature can or should reverse the Whitley holding and require that a different person than the signing voter sign the affidavit attesting to the validity of the signature of the petition signer.

The Court of Appeals made clear that the legislature had the power to reverse the holding in Whitley by amending the statute, stating "the General Assembly could have imposed (and may yet include) an express requirement that the circulator be independent from the signer ...."197 Even though the Court of Appeals was interpreting both constitutional and statutory language, the legislature could change the result merely by amending the statute to require separate signers, and no constitutional amendment would be required. Whitley states: "The [G]eneral [A]ssembly is authorized to enact statutes to further define the petitioning process, pursuant to Md. Const., art. XVl, 4." The Maryland Constitution states that "[t]he General Assembly shall prescribe by law the form of the petition, the manner for verifying its authenticity, and other administrative procedures which facilitate the petition process and which are not in conflict with the Article."199 The additional requirement that the circulator who signs the affidavit be a different person than the voter who signs the petition would not be in conflict with the Maryland Constitution, which requires the affidavit, but does not explicitly state whether it must be made by a separate person or not. Therefore, it would not violate the Maryland Constitution for the legislature to reverse the holding in Whitley by statute. ${ }^{200}$

The question, however, is whether the legislature should accept the Court of Appeals" "invitation" to amend the statute to include the requirement of having two individual signers? The Referendum Integrity Act introduced in 2013 contained just such a provision. ${ }^{201}$ If the Court of Appeals had so held, it would have kept the referendum at issue in Whitley off the ballot, because the number of petitions which would have been thrown out would have

\footnotetext{
${ }^{196}$ See supra Section C (explaining why this interpretation was not in accord with the statutory and constitutional language).

197 Whitley, $429 \mathrm{Md}$. at $162,55 \mathrm{~A} .3 \mathrm{~d} 37$.

${ }^{198}$ Id. at 140, n. 12,55 A.3d 37 .

${ }^{199} \mathrm{MD}$. CONST. art. XVI $\$ 4$.

${ }^{200} \mathrm{MD}$. CONST, art. XVI, $\S 4$.

201 "An Individual may not sign a signature page as both the circulator and a petitioner," H.B. 493, 2013 Leg., 433rd Sess. (Md. 2013); S.B. 673, 2013 Leg., 433rd Sess. (Md. 2013).
} 
dropped the valid signatures below the level required. But going forward, adding such a requirement in and of itself might not have much effect, since it would not put an end to the on-line process, or make it significantly more difficult. It would merely require the petition-generating program to be changed to instruct the signer to have someone else over the age of eighteen witness his signature and sign the affidavit.

For most honest people, that would not be an onerous requirement. The signer would just have to find an adult family member or friend willing to witness the signing of the petition and attest to having witnessed it. It would, therefore, have little if any effect on the number of legitimate petitions filed.

Would it, however, have the effect of reducing the number of fraudulent petitions that were submitted? There may certainly be some persons intent on committing fraud by, for example, signing for other voters in the household without their knowledge or permission, and attesting to the forged signatures. There is no evidence at this time, however, that they constitute a large, or even significant number. ${ }^{202}$ Just as importantly, anyone willing to falsely attest to a signature he himself had forged, would probably be willing to forge someone else's name to the attestation, since both are serious criminal violations. ${ }^{203}$

Even if some number of fraudulent petitions may be submitted using the on-line process, it might not indicate an increase in fraudulent petitions, since there has always been some amount of fraudulent petitions under the old inperson procedure. ${ }^{204}$ It would seem, therefore, that merely reversing Whitley and requiring a second signer, might have very little practical effect (neither making it significantly more difficult to obtain the required number of signatures nor significantly reducing the chances of fraudulent petitions).

202 See Samuel P. Langholz, Fashioning a Constitutional Voter Identification Requirement, 93 IOWA L. REV. 731 (2008) (discussing the rarily of household voler fraud).

${ }_{203}^{20}$ MD. CODE ANN., ELEC. LAW \$ 16-401; MD. CODE ANN., CRIM. LAW \$ 9-101(b).

204 In 2001 the ACLU brought suil challenging a referendum effort to overturn the General Assembly's addition of sexual orientation as a protected calegory under Maryland's antidiscrimination law. See Maryland's Antidiscrimination Act Goes into Effect After ACLU Defeats Attempts to Derail Landmark Law, ACLU (Nov. 21, 2001), hitps://www.aclu.org/lgbl-righis_hiv-aids/marylands-antidiscrimination-actw goes-effecl-after-aclu-defeats-attempts-derail. When, in discovery, the ACLU found more than 7,500 invalid signatures (some, but not all of which were the result of fraud), the sponsors of the Referendum conceded their failure and abandoned the petition effort. Letter from Deborah Jeon, Legal Director, ACLU of Maryland, to Linda Lamone, Administralor, Maryland Board of Elections, May 31, 2011 available at http:/www.aclu-md.org/uploaded_files/0000/0031/letter_state board elections.pdf (questioning the legality of the on-line petition process used by MDPetitions.com in 2012). 


\section{E. Should Maryland Impose Additional Restrictions and Regulations on the Signature-gathering Process and Petition Circulators?}

In addition to the requirement, discussed above, that the same individual may not sign as petitioner and circulator, the proposed Referendum Integrity Act contained several other amendments to the Maryland election laws governing the petition process. Some of these required the formation of a "Ballot Issue Committee" before an organization may "support the collection of signatures for a petition ...," and then subjected such committees to financial disclosure requirements similar to those applicable to other political action committees or candidates' election committees. ${ }^{205}$ Presumably, whether these are valid or not will depend on whether the pre-existing financial disclosure requirements of Maryland law applicable to other election related committees are valid, which is an issue beyond the scope of this article. ${ }^{206}$

One of the additional requirements in the Act which is relevant to this article is that "[b]efore acting as a circulator, an individual shall complete an online training course developed by the state board that provides instructions on state laws and regulations governing the process of circulating a petition. ${ }^{, 207}$ Whether this requirement is reasonable and constitutional depends on the distinction discussed above between the in-person circulation of petitions, where the same person solicits the signatures and then attests to them, and the on-line process, where the person attesting to the signature has a much more limited role, yet is still defined as a circulator under Maryland law.

If applied to in-person solicitors, this requirement might be valid under Meyers and Buckley, since knowledge of what is allowed and prohibited while soliciting signatures could be required. ${ }^{208}$ But if applied in the on-line situation to a "circulator" who is merely serving as a witness to the

${ }^{20}$ H.B. 493 Leg. 433rd Sess. (Md. 2013); S.B. 673, 2013 Leg., 433rd Sess. (Md. 2013).

${ }^{206}$ See generally Citizens United y. Fed. Election Comm'n. 558 U.S. 310 , 130 S.Ct. $876(2010)$.

${ }^{207}$ H.B. 493 Leg., 433 rd Sess. Md. 2013); S.B. 6732013 Leg., 433rd Sess. (Md. 2013).

${ }_{208}$ In Buckley, the Supreme Court seemingly approved of a requirement that the circulator's affidavit include a statement that "he or she has read and understands the laws governing the circulation of petitions." Buckley, 525 U.S. at 189, 192, 119 S.Ct. 636 (requiring circulators to take an on-line course about the law is certainly more burdensome than merely having them attest to having read and understand the law, so it is not entirely clear whether requiring in-person circulators to take such a course would be constitutional or not). 
petitioner's signature, it seems unnecessary and burdensome, and therefore likely unconstitutional under Meyers and Buckley.

Any future amendments to the Maryland petition process should recognize the differences between in-person and on-line solicitation of signatures and the different roles played by participants in each case. An organization sponsoring, organizing and funding a petition effort should be labeled a "sponsor," and should be subject to some regulation, including disclosure of the principals and financing. A person soliciting signatures inperson, or an organization or person soliciting signatures on-line, should be labeled a "circulator," subject to different requirements, such as being required to be familiar with the laws regarding solicitation of petition signatures. Finally, the person attesting that the signature is valid (who would normally be the actual circulator in the in-person process, but merely a friend or relative in the on-line process) should be called a "witness," with the only requirement that they be a person, other than the petitioner, who is at least eighteen years of age.

Another section of the Act would have made it illegal for circulators to be paid based on the number of petition signatures collected. ${ }^{269}$ As discussed above, ${ }^{210}$ this limitation is probably unconstitutional under Meyers, in which the Supreme Court held that a prohibition on paid circulators violated their First Amendment rights. Although the Supreme Court opinion did not discuss whether the result would have been different had the prohibition been limited to circulators paid per petition, the broad language of the opinion, coupled with the fact that most circulators in Colorado probably were paid per petition, would make it difficult to distinguish the proposed provision in the Referendum Integrity Act.

Another section of the Referendum Integrity Act would have made it significantly more difficult for voters to obtain the "prepopulated" on-line petitions approved by the Court of Appeals in Whitley, by requiring voters to enter their name "in the manner specified" by the election laws, and their address and date of birth "as they appear on the statewide voter registration list." $" 211$ It further stated that an on-line petition system "may generate a prepopulated signature page only for a registered voter whose personal identification information is entered in accordance" with the previous rule. ${ }^{212}$ The obvious intent of this paragraph is to keep persons from downloading prepopulated petitions for persons other than him or herself (usually others in the same household) and then fraudulently signing those other petitions.

While the possibility of fraud is real and the intent of the provision is proper, it may make it too difficult for some persons to obtain a pre-printed

\footnotetext{
${ }^{209}$ H.B. 493 Leg., 433rd Sess. (Md. 2013); S.B. 673 Leg., 433rd Sess. (Md. 2013).

${ }^{210}$ See supra text accompanying notes $146-54$.

${ }^{211}$ H.B. 493 Leg, 433rd Sess. (Md. 2013); S.B. 673 Leg., 433rd Sess. (Md. 2013).

$2 / 2 \mathrm{Id}$
} 
petition. One of the problems with the Maryland process in the past has been that many registered voters who signed a petition in good faith have had trouble understanding and complying with the requirement of entering their name "as it appears on the statewide voter registration list or the individual"s surname of registration and at least one full given name and the initials of any other names." 213 One of the benefits of the on-line process is that it supplies the voter with the name exactly as it appears on the statewide voter list, which many persons, in fact, do not know. With the on-line process used by MDPetitions.com, if the voter provides enough information for the computer program to identify him or her as a registered voter, the program preprints the petition with all of the required information in the correct form, thereby reducing the chance that the petition will be invalid because the format is not exactly right.

Prohibiting the on-line program from supplying the voter with information taken from a public, statewide voter registration list, unless the voter first enters exactly that same information in the proper form, is quite possibly too stringent a requirement, placing too great a burden on the "circulator" (which in this case would be MDPetitions.com) to survive constitutional challenge under Meyers and Buckley.

\section{CONCLUSION}

Maryland, which does not allow voters to petition for new laws, but does allow them to bring enacted laws to a referendum vote, has one of the most limited forms of direct voter participation in lawmaking among the states that have such a process. In spite of the fact that Maryland has a comparatively low requirement of three percent of the voters in the last gubematorial election, the referendum process has been used very infrequently in the past. In 2011-2012, however, an on-line assisted signature gathering process, approved by the Court of Appeals of Maryland in Whitley, helped opponents of three laws bring them all to a referendum vote at one election. Although all three laws survived the challenge, some politicians, fearing that the process had become too easy and would result in referendum votes on every controversial law, called for amendments to the signature-gathering process to both reduce the possibility of fraud and make it harder to bring a law to referendum.

Although opponents of two controversial laws passed in the 2013 legislative session failed to gather the required signatures, therefore undercutting the argument that the process had become too easy, it is too early to tell whether the new on-line process will result in overuse of the process in the future. Therefore, it may be reasonable for the General

${ }^{213}$ MD. CODE REGS. 33.06.03.06 (2010) (identification requirements for signers of petitions). 
Assembly to take a wait-and-see approach before making any changes to the petition process.

If the legislature does decide to act, it must make sure that any changes do not interfere with the free speech rights of petition circulators as laid out by the United States Supreme Court. It would not violate the United States Constitution to raise the required percentage of voters from three to five percent, but that would require amending the Maryland Constitution, which is unlikely to be possible. The legislature could reverse the holding in Whitley and require someone other than the petitioner to attest to the petitioner's signature. This would neither violate the United States Constitution nor require an amendment to the Maryland Constitution, but might not achieve the effect of making it significantly harder to gather the required number of signatures. The General Assembly could also impose additional restrictions on those supporting and circulating referendum petitions, but those restrictions would have to be "narrowly tailored to meet a compelling government purpose $e^{, 214}$ in order to survive constitutional scrutiny.

It would be helpful, in passing any further regulations governing the petition process, to distinguish between those directed at "circulators," who are attempting to gather signatures, from "witnesses," who merely attest to the validity of a voter"s signature. The present election laws, based on prior in-person signature gathering, do not make this distinction and assume that the same person will assume both functions. With computer-generated petitions this is not the case, and any change in the election laws should take this into account, prescribing different rules for each.

${ }^{214}$ Buckley, 525 U.S. at 192, n.12, 119 S.Ct. 636. 